\title{
A fully human transgene switch to regulate therapeutic protein production by cooling sensation
}

\section{Journal Article}

Author(s):

Bai, Peng; Liu, Ying; Xue, Shuai; Charpin-El Hamri, Ghislaine; Saxena, Pratik; Ye, Haifeng; Xie, Mingqi; Fussenegger, Martin (D)

Publication date:

2019-08

Permanent link:

https://doi.org/10.3929/ethz-b-000359797

Rights / license:

In Copyright - Non-Commercial Use Permitted

Originally published in:

Nature Medicine 25(8), https://doi.org/10.1038/s41591-019-0501-8

Funding acknowledgement:

785800 - Electrogenetics - Shaping Electrogenetic Interfaces for Closed-Loop Voltage-Controlled Gene Expression (EC) 


\title{
A fully human transgene switch to regulate therapeutic protein production by cooling sensation
}

Peng Bai ${ }^{1}$, Ying Liu ${ }^{1}$, Shuai Xue ${ }^{2}$, Ghislaine Charpin-El Hamri ${ }^{3}$, Pratik Saxena ${ }^{1}$, Haifeng $\mathrm{Ye}^{2}$, Mingqi Xie ${ }^{1}$, Martin Fussenegger ${ }^{1,4^{*}}$

${ }^{1}$ Department of Biosystems Science and Engineering, ETH Zurich, Mattenstrasse 26, CH4058 Basel, Switzerland

${ }^{2}$ Shanghai Key Laboratory of Regulatory Biology, Institute of Biomedical Sciences and School of Life Sciences, East China Normal University, Dongchuan Road 500, Shanghai 200241, People's Republic of China

${ }^{3}$ IUT Lyon 1, Département Génie Biologique, 74 Boulevard Niels Bohr, 69622 Villeurbanne Cedex, France

${ }^{4}$ Faculty of Science, University of Basel, CH-4031 Basel, Switzerland

${ }^{*}$ Correspondence: fussenegger@bsse.ethz.ch

\begin{abstract}
The ability to safely control transgene expression with simple synthetic gene switches is critical for effective gene- and cell-based therapies. Here, we harness the signaling pathway controlled by human transient receptor potential melastatin 8 (hTRPM8), a TRP channel family member ${ }^{1}$, to control transgene expression. hTRPM8 signaling is stimulated by menthol, an innocuous natural cooling compound, or by exposure to a cool environment (15$\left.18^{\circ} \mathrm{C}\right)$. By functionally linking hTRPM8-induced signaling to a synthetic promoter containing nuclear factor of activated T cells (NFAT) binding elements, we designed a synthetic gene circuit that is adjustable by exposure to a cool environment or to menthol. We show that this gene switch is functional in various cell types, and in human primary cells, as well as in mice implanted with engineered cells. In response to transdermal delivery of menthol, microencapsulated cell implants harboring this gene circuit coupled to expression of either of two therapeutic proteins, insulin or a modified activin type IIB receptor ligand trap protein $\left(\mathrm{mActRIIB}{ }^{\mathrm{ECD}}-\mathrm{hFc}\right.$ ), were able to alleviate hyperglycemia in alloxan-treated mice (a model of type 1 diabetes) or to reverse muscle atrophy in dexamethasone-treated mice (a model of muscle wasting), respectively. This fully human-derived orthogonal transgene switch should be amenable to a wide range of clinical applications.
\end{abstract}

\section{Main}

To develop synthetic biology-inspired treatment strategies, many gene switches have been built to respond to various signal inputs and transduce them into controlled outputs ${ }^{2}$. 
However, most of these switches contain non-human genetic components, including prokaryotic transcription factors and rodent-derived components. In humans, these xenogeneic materials could trigger immune responses leading to partial or complete loss of transgene regulation and expression ${ }^{3,4}$ as well as serious adverse reactions, including anaphylactic reactions and cardiac arrest ${ }^{5}$. One might circumvent the issue by building gene switches with minimal components entirely of human origin, but this is technically challenging ${ }^{6}$, because native human receptors have generally evolved to sense and regulate endogenous signaling molecules such as hormones and other metabolites, rendering crossinteractions with host metabolism/signaling unavoidable. We focused on transient receptor potential (TRP) channels as candidates to distinguish between intentional and non-intentional stimulation in vivo. Among them, TRPV1, TRPA1 and TRPM8 sense temperature thresholds, as well as physiologically inert natural chemical stimuli ${ }^{7}$. We selected TRPM8 as the best candidate for therapeutic transgene regulation due to its highly specific response to cooling sensation triggered by a specific temperature range or to menthol, which is widely used in the food industry as a flavoring agent ${ }^{9}$ and also as a penetration-enhancing component and in cooling formulations, particularly in dermatology ${ }^{1,8,9}$.

Capitalizing on these characteristics of TRPM8, we designed a synthetic gene circuit of entirely human origin. By connecting human TRPM8 channel-induced intracellular calcium increase to calcium-dependent activation and mobilization of nuclear factor of activated $\mathrm{T}$ cells $(\mathrm{NFAT})^{10}$, which binds and initiates transcription from a synthetic promoter pMX57 $\left(\mathrm{P}_{\mathrm{NFAT} 3}-\mathrm{SEAP}-\mathrm{pA}\right)^{11}$, external thermal and chemical stimuli could be captured and coupled with gene expression (Figure 1A). Since signaling activation of NFAT through TRPM8 has not been reported before, we did additional control experiments to confirm calcium-regulated NFAT nuclear translocation (Extended Data Figure 1A) and calcineurin-dependent NFATactivity (Extended Data Figure 1B) in TRPM8-transfected cells. When comparing the substrate-specificity of TRPV1-, TRPM8- and TRPA1-based gene switches ${ }^{7}$, we found that the human TRPA1 (pPB109, $\mathrm{P}_{\mathrm{hCMv}}$-hTRPA1-pA)-based gene switch marginally responds to cinnamaldehyde, a cinnamon flavonoid, but transgene induction in response to a chillingly cold environment ${ }^{12}\left(4^{\circ} \mathrm{C}\right)$ was not observed (Figure 1B). On the other hand, the human TRPM8 (phTRPM8, $\mathrm{P}_{\mathrm{hCMV}}$-hTRPM8-pA)-controlled gene switch is highly responsive to a pleasingly cool environment $t^{8,13}\left(15^{\circ} \mathrm{C}\right)$ and to menthol. Gene transcription through human TRPV1 (pPB108, $\mathrm{P}_{\mathrm{hCMV}}-\mathrm{hTRPV1-pA)}$ was regulatable by hot sensation ${ }^{14}\left(42^{\circ} \mathrm{C}\right)$ and capsaicin, an irritating compound from hot chili pepper (Figure 1B). Importantly, TRPM8 was insensitive to capsaicin (Extended Data Figure 1C), other monoterpenes with a mint-like flavor (Extended Data Figure 1C), and potential agonists that might be encountered in human metabolism ${ }^{15}$ (Extended Data Figure 1D), thus demonstrating high specificity for temperature 
(Figure 1B) and menthol (including menthol esters and derivatives) (Extended Data Figure 1C). Therefore, the combination of mild sensory cues with the greatest transgene induction among these three channels made human TRPM8 the preferred choice for building a transgene switch.

To optimize the system, we linked the signaling activation of hTRPM8 to different calciumresponsive promoters. The promoter constructs tested could all mediate transgene induction; they contain either NFAT-binding sites derived from different genomic loci (pMX57, IL4 promoter; pHY30, IL2 promoter) or three different $\mathrm{Ca}^{2+}$ response elements placed in cisarrangement (pYL1), i.e. cyclic adenosine monophosphate response elements (CRE), serum response element (SRE) and IL2-derived NFAT response elements ${ }^{16}$. We selected pMX57 for further characterization, based on its low basal expression in the absence of menthol $(0.58 \pm$ $0.10 \mathrm{U} / \mathrm{L})$ and its highest fold-activation following stimulation with menthol $(20.33 \pm 0.88$ U/L; 35.1-fold) (Figure 1C). In fact, the IL4-derived NFAT-promoter $\mathrm{P}_{\mathrm{NFAT3}}$ used in pMX57 confirmed the specificity for menthol-mediated calcium increase, while higher basal expression levels observed with the IL2-derived $\mathrm{P}_{\mathrm{NFAT1}}$ promoter (pHY30) might result from cross-activity with endogenous PKC-agonists and an additional AP-1 site ${ }^{17}$. We also confirmed transgene induction via pMX57 with TRPM8 channels originated from rat and mouse (Extended Data Figure 1E). Interestingly, when cell populations expressing

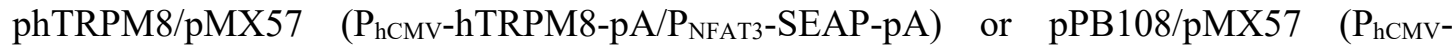

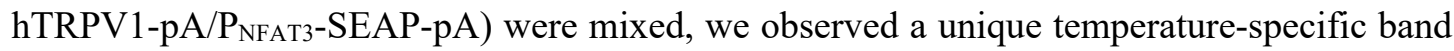
pass filter-like regulation, characterized by gene expression that was exclusively permitted in hot $\left(42^{\circ} \mathrm{C}\right)$ and $\operatorname{cool}\left(18^{\circ} \mathrm{C}\right)$ environments (Extended Data Figure $\left.1 \mathrm{~F}\right)$.

To assess the versatility of the cooling sensation-transduced gene switch ( $\mathrm{Cool}_{\text {Sens }}$ ), we transfected pPB112/pPB111 ( $\left.\mathrm{P}_{\mathrm{hEF} 1 \alpha}-\mathrm{hTRPM} 8-\mathrm{pA} / \mathrm{P}_{\mathrm{NFAT5}}-\mathrm{SEAP}-\mathrm{pA}\right)$ into human keratinocyte cells (HaCaT), human T lymphocyte cells (Jurkat), human mesenchymal stem cells (hMSCTERT), baby hamster kidney cells (BHK-21), and human primary mesenchymal stem cells. Reporter gene expression was menthol-dependent in all tested cell types (Figure 2A), suggesting that $\mathrm{Cool}_{\text {sens }}$ is functionally robust and compatible with a wide range of applications. Exposure of $\mathrm{Cool}_{\text {Sens }}$ to menthol dose-dependently induced expression of secreted alkaline phosphatase (SEAP) (Figure 2B). Menthol-controlled transcriptional activation was abrogated in the absence of hTRPM8 (Figure 2B), indicating that the system is fully hTRPM8-dependent. Furthermore, when Coolsens was induced with menthol pulses of different concentration and duration (Figure 2C; Extended Data Figure 1G), a stimulation time of 0.5-1 h was sufficient to activate transgene expression (Figure 2C; Extended Data Figure $1 \mathrm{G})$. This transgene switch also exhibited fast kinetics, affording significant SEAP 
induction within $3 \mathrm{~h}$ (Figure 2D), and showing excellent reversibility in response to cycles of exposure $(\mathrm{ON})$ and withdrawal (OFF) of menthol at 24-h intervals (Figure 2E).

To further evaluate the robustness of the system, we cultured Coolsens cells under sub-optimal conditions, such as lactic acidosis or low glucose, and scored SEAP production capacity (Figure 2F). We also simulated the influence of hypoxia-induced signaling activation on the system, and found that $\mathrm{Cool}_{\text {Sens }}$ cells retained menthol-responsiveness (Figure 2F), suggesting that $\mathrm{Cool}_{\text {Sens }}$ would be resistant to stress-related environments. Moreover, we found no apparent crosstalk between the system and mainstream signaling pathways, including $\mathrm{G}_{\mathrm{aq} / 11^{-}}$ mediated calcium increase through the activation of G protein-coupled receptor 40 (GPR40), $\mathrm{G}_{\text {as }}$-mediated production of cyclic AMP triggered by stimulation of $\mathrm{G}$ protein-coupled bile acid receptor 1 (TGR5), and proinflammatory nuclear factor NF- $\mathrm{BB}$ activation in response to toll-like receptor 2 (TLR2) signaling (Figure 2G). Interestingly, although both GPR40 and TRPM8 triggered $\mathrm{Ca}^{2+}$ elevation upon receptor stimulation (Supplementary Movie 1), the $\mathrm{P}_{\mathrm{NFAT3}}$ promoter (pMX57; $\mathrm{P}_{\mathrm{NFAT3}}-\mathrm{SEAP-pA}$; Extended Data Figure 2A) was more specific than the high-sensitivity $\mathrm{P}_{\text {CRE-SRE-NFat }}$ promoter (pYL1; P PRE-SRe-NFAT-SEAP-pA; Extended Data Figure 2B) in reporting menthol-dependent TRPM8-activation in human cells, suggesting that different calcium-responsive promoters should be used to capture different intracellular calcium signaling dynamics ${ }^{18}$. In addition, we showed that $\mathrm{Cool}_{\text {Sens }}$ was not sensitive to physiological levels of NFAT-agonists that could cross-activate the $\mathrm{P}_{\mathrm{NFAT} 3}$ promoter (Extended Data Fig. 2C), suggesting its independence from endogenous PKCsignaling and unresponsiveness to calcium increase through endogenous receptors ${ }^{17}$.

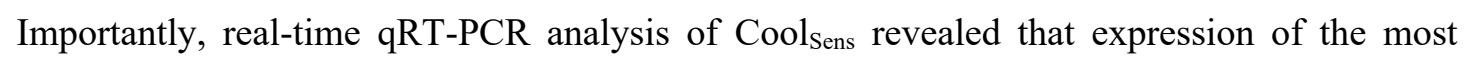
representative endogenous NFAT-target genes ${ }^{10,19,20}$ remained largely unaffected by overexpression and/or persistent stimulation of the TRPM8 channel for up to 30 days (Extended Data Fig. 2D). These results indicate that the system is robust and orthogonal, with the ability to adapt to varying host physiological status and to avoid interference from endogenous molecules or signaling pathways, a feature that is highly desirable for long-term gene regulation applications in humans.

Advances in cell encapsulation technology have enabled the encapsulation of cells into artificial, semipermeable membranes or biocompatible materials with customized pore size to protect them from host immune rejection ${ }^{21}$, enabling spatial control of transgenic cells after implantation ${ }^{21}$. Therefore, we examined the adaptability of Coolsens cells to different encapsulation approaches and fabrication biomaterials. We observed consistent functionality of $\mathrm{Cool}_{\text {Sens }}$ cells encapsulated with all cell transplantation technologies tested in this study, including alginate- or cellulose-based microcapsules and hollow-fiber macrocapsules 
(Extended Data Figure 3). To assess the performance of $\mathrm{Cool}_{\text {Sens }}$ in vivo, we

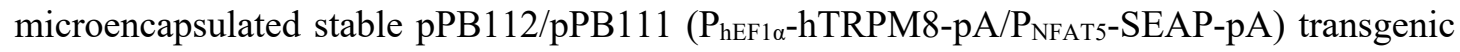
cells into alginate-poly-(L-lysine)-alginate beads, a clinically compatible technology used for encapsulation of human islets to treat type-1 diabetes ${ }^{22}$. Mice with a subcutaneous transgenic cell implant were treated topically with different concentrations of homemade menthol ointments or menthol-containing products, such as Tiger Balm ${ }^{\circledR}$ Rot N, Salonpas ${ }^{\circledR}$ pain relief patches and Eagle ${ }^{\circledR}$ medicated oil. These treatments all induced significant SEAP expression in the blood (Figure 3A). Since in situ production of therapeutic proteins in deep-tissue locations may also be desirable, we further implanted the Coolsens stable transgenic cells intraperitoneally into mice, and confirmed their functionality in deeply located tissue sites, based on the increase of blood SEAP levels in response to oral administration of different doses of menthol solutions (Figure 3B). Importantly, because mammals are endothermic animals capable of maintaining a constant body temperature, implanted TRPM8-transgenic cells in mice were precisely controlled by intentional menthol uptake (Figure 3B; Extended Data Figure 4A) or topical application of specific doses of menthol (Figure 3A), and were not affected by environmental temperature fluctuations (Extended Data Figure 4B) or inhalation of menthol vapor (Extended Data Figure 4C), indicating good insulation of Coolsens from environmental disturbances that would occur in daily-life settings. These results validated the functionality of $\mathrm{Cool}_{\text {Sens }}$ in vivo, and its orthogonal regulation by menthol, which can be used both percutaneously and orally to remotely control therapeutic gene expression at targeted tissue sites.

In order to showcase the applicability of this orthogonal gene switch for gene- and cell-based therapies, we used it to regulate the expression and secretion of therapeutically relevant proteins in chronic disease models, in which constant control over drug dosage is required.

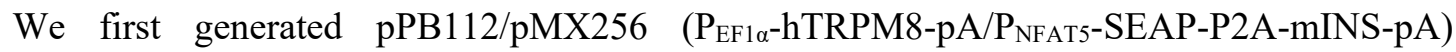
stable cells (Cool $\left.{ }_{\mathrm{INS}}\right)$ for long-term and reversible delivery of insulin in type-1 diabetic mice, characterized the kinetics of Cool INS-mediated protein secretion in mice (Extended Data Figure 5), and found that diabetic mice bearing a Cool ${ }_{\text {INS }}$ cell implant and receiving menthol showed significantly lower fasting blood glucose levels and postprandial glucose levels over an experimental timescale of one month, as compared to diabetic mice with menthol administration alone (Extended Data Figure 6). Longer functionality of microencapsulationbased cell implants in vivo can be achieved by attenuating host-mediated foreign-body responses, such as pericapsular fibrotic overgrowth $(\mathrm{PFO})^{23,24}$ (Extended Data Figure 7), either by maximizing the content of autologous/isogenic cell components in the gene switch design $^{25,26}$ (Extended Data Figure 8 ) or by developing enhanced capsule materials with a lower susceptibility to $\mathrm{PFO}^{24}$. When we percutaneously applied menthol to Cool INS-implanted 
diabetic mice, fasting glycaemia levels of the treatment group remained close to those of healthy control mice throughout the entire study (Figure 3C). Blood insulin levels were also

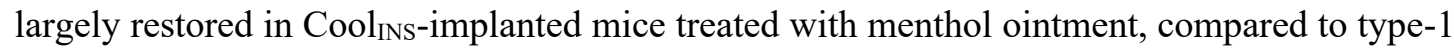
diabetic mice without ointment application (Figure 3D). Glucose-tolerance tests performed at day 2 and day 9 further confirmed menthol-dependent re-establishment of postprandial glucose metabolism by the Cool ${ }_{\text {INS }}$ cell implant in mice over a prolonged period (Figure 3E, F). Moreover, the system showed excellent reversibility in vivo, efficiently turning transgene expression on and off in response to the application or withdrawal of menthol (Figure 3G). Correspondingly, blood glucose levels were reversibly adjusted in response to the timed menthol delivery (Figure 3H). Although these data confirm that insulin production by the current NFAT-based transcriptional system (Extended Data Figure 9) is sufficient to achieve long-term control of blood glucose homeostasis in vivo (Extended Data Figure 6), achievement of faster insulin secretion dynamics could be a useful target for future work aiming towards preclinical development of cell-based diabetes therapies ${ }^{27}$.

Muscle wasting has a huge impact on the quality of life in aged and chronically ill human populations, and continues to be a significant clinical problem in patients with various catabolic conditions, including sepsis, AIDS, severe injury, uremia, heart failure, and cancer $^{28,29}$. One promising treatment strategy is based on the injection of a synthetic immunofusin of the extracellular domain of activin receptor type IIB (mActRII $\left.{ }^{\mathrm{ECD}}-\mathrm{hFc}\right)^{30}$, which traps excessive myostatin in the blood circulation to prevent the initiation of signaling pathways involved in muscle atrophy ${ }^{30,31}$. To demonstrate the potential of cell-based drug delivery systems for treating muscle wasting, we used a dexamethasone-induced muscle

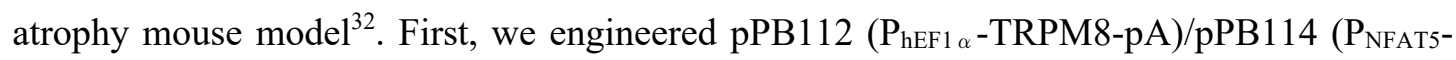
$\left.\mathrm{mActRIIB}^{\mathrm{ECD}}-\mathrm{hFC}-\mathrm{pA}\right)$ transgenic cells and confirmed menthol-dependent production of $\mathrm{mActRII}{ }^{\mathrm{ECD}}-\mathrm{hFc}$ in vitro (Figure $4 \mathrm{~A}$ ). Next, functionality of $\mathrm{mActRII}{ }^{\mathrm{ECD}}-\mathrm{hFc}$ was verified by its inhibition of activin type IIB receptor signaling activation, which was captured through a reporter construct driving luminescence expression (Figure 4B). In the murine muscle atrophy model, mice bearing subcutaneous cell implants and treated with menthol showed increased serum levels of mActRII ${ }^{\mathrm{ECD}}-\mathrm{hFc}$ (Figure $4 \mathrm{C}$ ). Changes in body weight revealed a significantly smaller decrease in the $\mathrm{Cool}_{\mathrm{ActRI}}$-implanted and menthol-treated group than in the $\mathrm{Cool}_{\mathrm{ActRI}}$-implanted group without menthol application or in the group implanted with control cells ( Coolsens $_{\text {s }}$ devoid of $\mathrm{mActRII}{ }^{\mathrm{ECD}}-\mathrm{hFc}$ expression (Figure 4D). Specifically,

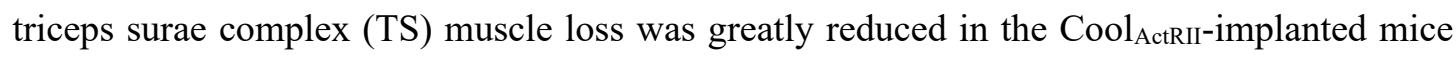
receiving menthol ointment, compared with the other groups (Figure 4E). There was also a 
clear visual difference in muscle preservation between individual mice receiving therapeutic cells or control cells (Figure 4F).

Recent advances in gene delivery and cell encapsulation technologies have enabled substantial clinical success for gene- and cell-based therapies ${ }^{33,34}$. However, several barriers must be overcome before these therapies can be widely accepted for a broad range of diseases $^{6,35}$. To date, most gene regulatory systems have been built on prokaryotic response regulators fused to virus-derived effector domains ${ }^{2}$. This has raised concerns about possible pleiotropic effects and the development of immune responses directed against the xenogeneic regulators used in the transgene expression system. Indeed, such immune responses have been documented when applying the widely used tetracycline-dependent systems in non-human primates, leading to the complete loss of transgene regulation and expression in a large majority of cases $^{4,6}$. Although current cell encapsulation technologies can greatly enhance xenogeneic cell survival in vivo, the presence of xenogeneic materials is still a key factor that hinders the further extension of long-term cell viability inside capsules ${ }^{36}$. Xenogeneic molecules or "shed antigens" can gradually cross the capsular membrane and trigger significant inflammatory cell reactions that could severely harm, and possibly destroy the encapsulated cells as well as their surrounding tissues ${ }^{34}$. Another key factor to consider when designing gene circuits for future gene- and cell-based therapies is the characteristics of the trigger molecule. So far, human components-derived gene switches have been developed to exclusively respond to either endogenous signalling molecules ${ }^{37,38}$ or to traceless inducers such as light ${ }^{40}$ and smell ${ }^{39}$, which are ubiquitous environmental cues rendering precise control over dosage virtually impossible in a putative clinical context.

In this study, we took advantage of native human sensors with high ligand-specificity, that are solely activated by exogenous but natural cues, such as menthol. Therefore, maximal control capacity, minimal potential side effects from trigger molecules, and optimal pharmacokinetics in mammalian organisms can be achieved. Furthermore, this system is compatible with cell transplantation technologies such as alginate, which are currently being employed in clinical trials $^{22}$. Encapsulated $\mathrm{Cool}_{\text {Sens }}$ implants remained functional across different sites in the body e.g. subcutaneous and intra-peritoneal, and could provide spatial control of therapeutic release at different tissues of interest. When tested in different rodent disease models, menthol-based regulatory systems offered robust and flexible means to precisely tune the expression of therapeutic proteins, and there was a direct relationship between transgene expression and the resulting physiological/clinical effect. The versatile administration routes of menthol ensure easy clinical implementation, either via regular food or drink consumption or through 
intermittent applications of formulated menthol ointment, which should not greatly disrupt patients' routines.

We believe that this work provides an in-depth illustration of how to construct human gene regulation systems that are simple, safe, and readily adaptable into various clinical settings. From the viewpoint of clinical translation, transgene regulation systems should ideally satisfy all of the following requirements: (i) basic functionality of the circuit in terms of foldinduction (Figures $1 \& 2$ ) and achievement of tunable, reversible and physiological secretion levels for one or many therapeutic outputs (Figures $3 \& 4$ ), (ii) maximal use of humanderived circuit components to reduce the potential for host-mediated foreign-body responses $^{25,26,34,36}$ (Extended Data Figures 7 \& 8), (iii) capability to synchronize with endogenous signaling pathways (Supplementary Movie 1) in order to increase the control capacity of various cell types, and (iv) a clear-cut distinction between intentional and nonintentional activation in vivo (Extended Data Figures 1D \& 4). This work should help to guide the future design of gene regulation systems without inherent toxicity by avoiding the use of nonhuman or viral transcription factors and/or regulatory proteins that involve potential risks of immune responses.

Acknowledgments. We thank Prof. Félix Viana for providing prTRPM8, Prof. Frank Kühn for providing phTRPM8, Prof. Xinzhong Dong for providing pmTRPM8. We also thank Marie Daoud-El Baba, Jian Jiang and Jianli Yin for supporting the in vivo work; Verena Jäggin, Mariangela Di Tacchio and Ying Zhang for assistance with flow cytometry; Tom Lummen for help with time-lapse microscopy and Aaron Ponti for support with statistical analysis. This work was supported by a personal fellowship from the Chinese Scholarship Council to Peng Bai, by the NCCR Molecular Systems Engineering and in part by the European Research Council advanced Grant (ElectroGene, 785800) (both to M.F.). This work was also financially supported by grants from the National Natural Science Foundation of China (NSFC: No. 31861143016), the Science and Technology Commission of Shanghai Municipality (No. 18JC1411000) and the Thousand Youth Talents Plan of China to H.Y.

Author contributions. P.B. and M.F conceived the project. P.B., Y.L., M.X., P.S., H.Y. and M.F. designed the experiments. P.B., Y.L., M.X., P.S., H.Y. and M.F. analyzed the results. P.B., Y.L., S.X., P.S., and G.C.-E.H. performed the experimental work. P.B., Y.L., M.X., P.S. and M.F. wrote the manuscript.

Competing financial interests. The authors declare no competing financial interests. 


\section{Methods}

\section{Chemicals and inducer compounds.}

Menthol (200 mM stock solution in ethanol; cat. no. 63660-100G), capsaicin (200 mM stock solution in ethanol; cat. no. M2028-50MG), cholic acid (10 mM stock solution in $\mathrm{ddH}_{2} \mathrm{O}$; cat. no. C9282), oleic acid (cat. no. 112801, $50 \mathrm{mM}$ DMSO stock solutions), peptidoglycan (PGN) from Staphylococcus aureus (cat. no. tlrl-pgns2), ethanol (EtOH; cat. no. 02860), dexamethasone 21-phosphate disodium salt (cat. no. D1159-500MG), alloxan monohydrate (cat. no. A7413), recombinant insulin (cat. no. I0516) and olive oil (cat. no. O1514) were purchased from Sigma-Aldrich (Buchs, Switzerland). Cyclosporin A (cat. no. 3024), Lmenthyl lactate (cat. no. W374800-100G), L-menthyl acetate (cat. no. W266825-100G-K), ()-isopulegol (cat. no. 59770-5ML), eucalyptol (cat. no. 29210-1ML), WS-12 (cat. no. W05195MG), camphor (cat. no. 21310-50G-F), carvone (cat. no. 12,493-1) and menthone (cat. no. 95401-1ML) were purchased from Sigma-Aldrich and diluted in EtOH to make $200 \mathrm{mM}$ stock solutions. Testosterone (cat. no. 46923-250MG-R, Sigma-Aldrich), VEGF 165 (cat. no. 100-20, Peprotech), angiotensin II (cat. no. A9525-1MG, Sigma-Aldrich), L-norepinephrine (cat. no. 74480-100MG, Sigma-Aldrich), acetylcholine (cat. no: A2661-25G, Sigma-Aldrich) and IL6 (cat. no. H7416, Sigma-Aldrich) were freshly dissolved in water prior to each experiment. Cobalt(II) chloride hexahydrate $(\mathrm{CoCl} 2 \cdot 6 \mathrm{H} 2 \mathrm{O}$, cat. no. 423571000), puromycin dihydrochloride (cat. no. A1113803) and Zeocin ${ }^{\mathrm{TM}}$ selection reagent (cat. no. R25005) were purchased from ThermoFisher Scientific (Reinach, Switzerland). Vaseline was bought in a local Swiss pharmacy, Tiger Balm ${ }^{\circledR}$ menthol ointment was bought in a German pharmacy, and Salponpas ${ }^{\circledR}$ menthol patch and Eagle ${ }^{\circledR}$ medicated oil were bought in a local Asian shop. Peppermint essential oil and peppermint leaves were bought from local supermarkets in Shanghai, China. Homemade menthol ointment was formulated by dissolving different quantities of menthol in olive oil/vaseline mixture $(1: 1)$ at $80^{\circ} \mathrm{C}$, followed by cooling. Clophosome $^{\circledR}$-A (Clodronate Liposomes; cat. no. F70101C-A) was purchased from Formumax, USA.

\section{Vector design.}

Comprehensive design and construction details for all expression vectors are provided in Table S1.

\section{Cell culture and transfection.}

Human embryonic kidney cells (HEK293, ATCC: CRL-11268), baby hamster kidney cells (BHK-21, ATCC: CCL-10), human keratinocyte cell line $\mathrm{HaCaT}^{41}, \mathrm{C} 2 \mathrm{C} 12$ myoblast cells $\left(\mathrm{ATCC}^{\circledR} \mathrm{CRL}-1772^{\mathrm{TM}}\right.$ ) and telomerase-immortalised human mesenchymal stem cells ${ }^{42}$ (hMSC-TERT) were cultured in Dulbecco's modified Eagle's medium (DMEM; Invitrogen, 
Basel, Switzerland; cat. no. 52100-39) supplemented with $10 \%(\mathrm{v} / \mathrm{v})$ fetal bovine serum (FBS; Sigma-Aldrich, Munich, Germany; cat. no. F7524) and 1\% (v/v) penicillin/ streptomycin solution (Sigma-Aldrich). Jurkat T cells (DSMZ no.: ACC 282) were cultured in RPMI (Life Technologies) supplemented with 10\% (v/v) fetal bovine serum (FBS, SigmaAldrich) and $1 \%(\mathrm{v} / \mathrm{v})$ penicillin/streptomycin solution (Sigma-Aldrich). Patient-derived hMSCs $^{43}$ were cultured in DMEM/F-12 GlutaMAX (ThermoFisher Scientific) containing $10 \%$ FBS, $1 \%(\mathrm{v} / \mathrm{v})$ penicillin/streptomycin solution and $4 \mathrm{ng} / \mathrm{mL}$ of basic fibroblast growth factor (Invitrogen) for propagation. All cell types were cultivated at $37^{\circ} \mathrm{C}$ in a humidified atmosphere containing $5 \% \mathrm{CO}_{2}$. For temperature stimulation in experiments related to Fig. $1 \mathrm{~b}$ and extended data Fig. 1f, cells seeded on 24-well plates were incubated on a thermal mixer for $1 \mathrm{~h}$ at the indicated temperatures $\left(4^{\circ} \mathrm{C}, 15^{\circ} \mathrm{C}\right.$ or $\left.42^{\circ} \mathrm{C}\right)$ and then returned to the $37^{\circ} \mathrm{C}$ incubator.

HEK293, hMSC-TERT, and BHK-21 cells were transfected using an optimized polyethyleneimine (PEI)-based protocol ${ }^{44}$. For transfection of BHK-21, HEK293 and hMSCTERT, $5 \times 10^{4}$ cells seeded per well of a 24 -well plate $20 \mathrm{~h}$ before transfection were incubated with a transfection solution containing $0.55 \mu \mathrm{g}$ DNA plasmids and $2.2 \mu \mathrm{L}$ of PEI (polyethyleneimine; MW 40,000, stock solution $1 \mu \mathrm{g} / \mu \mathrm{L}$ in $\mathrm{ddH}_{2} \mathrm{O}$; Polysciences, Eppelheim, Germany; cat. no. 24765-2). For transfection of Jurkat T cells, $5 \times 10^{5}$ suspension cells per well of a 24-well plate were incubated with a transfection solution containing $0.55 \mu \mathrm{g}$ DNA plasmid and 2.2 $\mu \mathrm{L}$ of PEI. Equal amounts of DNA plasmids were used for co-transfections. Transfection of patient-derived hMSCs was done with the Neon electroporation system (Thermofisher Scientific). In brief, about $3 \times 10^{5}$ cells were suspended in electroporation buffer and $2000 \mathrm{ng}$ of plasmid was added for each transfection. Three pulses of $20 \mathrm{~ms}$ at $1200 \mathrm{mV}$ were used for electroporation and the cells were re-seeded into 6-well plates. After $6 \mathrm{~h}$, the medium was changed before the quantification of the expression of genes of interest. Cell concentrations and viability were profiled with a CASY ${ }^{\circledR}$ Cell Counter and Analyzer System Model TT (Roche Diagnostics GmbH, Mannheim, Germany).

\section{Analytical assays.}

SEAP. Production of human placental secreted alkaline phosphatase (SEAP) in culture was quantified by means of light absorbance measurement using a p-nitrophenyl phosphate-based assay $^{45,46}$. Samples $(80 \mu \mathrm{L})$ were first heat-inactivated for $30 \mathrm{~min}$ at $65^{\circ} \mathrm{C}$ and then transferred to a 96-well plate containing $100 \mu \mathrm{L} 2 \times$ SEAP assay buffer $(2 \mathrm{M}$ diethanolamine, $2 \mathrm{mM} \mathrm{L}$ homoarginine hydrochloride, $1 \mathrm{mM} \mathrm{MgCl}$, $\mathrm{pH}$ 9.8). After addition of $20 \mu \mathrm{L} 120 \mathrm{mM} \mathrm{pNPP}$ (4-nitrophenyl phosphate, disodium salt, hexahydrate, Acros Organics, Geel, Belgium; cat. no. 128860100), the increase in light absorbance was measured at $405 \mathrm{~nm}$ for $30 \mathrm{~min}$. Serum 
levels of SEAP were quantified using a chemiluminescence-based assay (Roche Diagnostics GmbH, Mannheim, Germany, ref. no. 11779842001).

Insulin. mINS levels in culture supernatants and mouse serum were quantified with a Mouse Insulin ELISA kit (Mercordia, Uppsala, Sweden; cat. no. 10-1247-01; lot no. 26061).

Glycemia. Blood glucose levels of mice were measured using a commercial glucometer (Contour ${ }^{\circledR}$ Next; Bayer HealthCare, Leverkusen, Germany; detection range: 0.5-35 mM).

Firefly Luciferase. Firefly luciferase levels were profiled using the Bright-Glo ${ }^{\mathrm{TM}}$ Luciferase Assay System (Promega AG, Dübendorf, Switzerland; cat. no. E2610).

NanoLuc. NanoLuc levels in cell culture supernatants were quantified using the Nano-Glo Luciferase Assay System (N1110, Promega). A $7.5 \mu \mathrm{L}$ aliquot of sample was incubated for 5 min with $7.5 \mu \mathrm{L}$ buffer:substrate mix (50:1) in a 384-well plate (781076, Greiner Bio One), and luminescence was measured with a Tecan Genios PRO multiplate reader (Tecan AG).

Human $\operatorname{IgG}$. Expression levels of $\mathrm{hFc}$ or $\mathrm{mActRIIB}^{\mathrm{ECD}}-\mathrm{hFC}$ in culture supernatants or mouse serum were quantified with a human IgG ELISA kit (Immunology Consultants Laboratory, Inc., Portland, USA; cat. no. E-80G; lot no. 35).

Serum inflammatory cytokines. Mouse serum levels of TNF $\alpha$, IFN- $\gamma$ and IL-6 were quantified with mouse Ultra-sensitive TNF $\alpha$ ELISA (cat. no. EK282HS-96; lot no. A282H81224, MultiSciences, China), IFN- $\gamma$ ELISA (cat. no. EK280/3; MultiSciences, China) and IL-6 ELISA (cat. no. EK282/3; MultiSciences, China) respectively.

\section{Quantitative RT-PCR.}

Total RNA of each cell population was extracted using the ZR RNA MiniPrep kit (Zymo Research). qRT-PCR with total RNA was performed using High-Capacity cDNA Reverse Transcription Kit (Invitrogen) and SYBR Green PCR Mastermix with custom-designed primers (Table S2). The Eppendorf Realplex Mastercycler (Eppendorf $\mathrm{GmbH}$ ) was set to the following amplification parameters: $3 \mathrm{~min}$ at $95^{\circ} \mathrm{C}$, then 40 cycles of $3 \mathrm{~s}$ at $95^{\circ} \mathrm{C}$, followed by $1 \mathrm{~min}$ at $60^{\circ} \mathrm{C}$. The relative threshold cycle $(\mathrm{Ct})$ was determined and normalized to the endogenous beta-actin transcript. The fold change for each transcript relative to the control was calculated using the comparative $\mathrm{Ct}$ method $^{47}$.

\section{Generation of stable cell lines.}


The polyclonal HEK population transgenic for stable expression of human TRPM8 and $\mathrm{P}_{\mathrm{NFAT5} \text {-SEAP (stable Cool }}$ Sens) was constructed by co-transfecting $2 \times 10^{5}$ HEK293 cells $/ \mathrm{mL}$

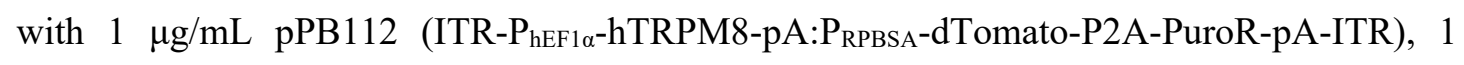

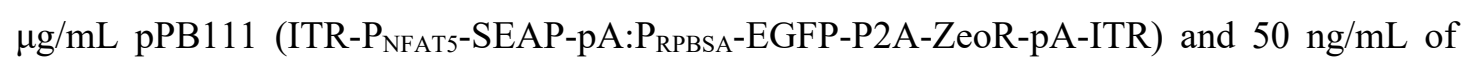
the Sleeping Beauty transposase expression vector pCMV-T7-SB100 ( $\left.\mathrm{P}_{\mathrm{hCMV}}-\mathrm{SB} 100 \mathrm{X}-\mathrm{pA}\right)^{48}$. After selection for two passages with $2.5 \mu \mathrm{g} / \mathrm{mL}$ puromycin and $300 \mu \mathrm{g} / \mathrm{mL}$ Zeocin, the surviving population was FACS-sorted into three different subpopulations based on redfluorescence and EGFP intensities. The 15\% subpopulation with the highest dTomato and EGFP intensity showed the best performance and thus was used for follow-up experiments.

The polyclonal HEK population transgenic for stable expression of human TRPM8 and

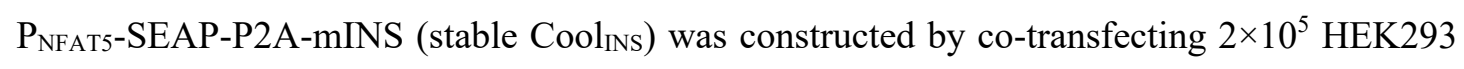

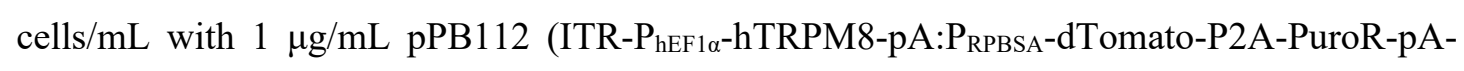

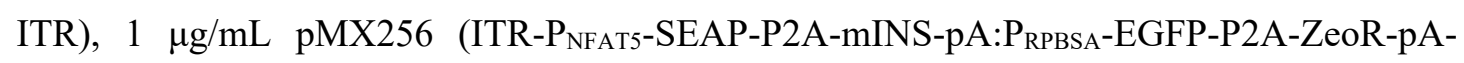
ITR) and $50 \mathrm{ng} / \mathrm{mL}$ of the Sleeping Beauty transposase expression vector pCMV-T7-SB100 $\left(\mathrm{P}_{\mathrm{hCMV}} \mathrm{SB} 100 \mathrm{X}-\mathrm{pA}\right)^{56}$. After selection for two passages with $2.5 \mu \mathrm{g} / \mathrm{mL}$ puromycin and 300 $\mu \mathrm{g} / \mathrm{mL}$ Zeocin, the surviving population was FACS-sorted into three different subpopulations based on red-fluorescence and EGFP intensities. The 15\% subpopulation with the highest dTomato and EGFP intensity showed the best performance and thus was used for follow-up experiments.

The polyclonal HEK population transgenic for stable expression of human TRPM8 and $\mathrm{P}_{\mathrm{NFAT5}}-\mathrm{mActRIIB}{ }^{\mathrm{ECD}}$-hFC (stable Cool $_{\text {ActRII }}$ ) was constructed by co-transfecting $2 \times 10^{5}$

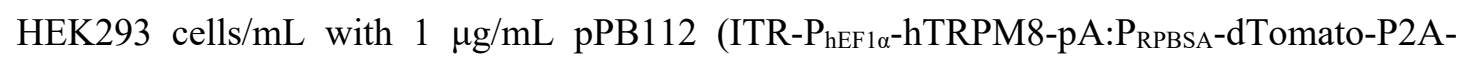
PuroR-pA-ITR), $1 \mu \mathrm{g} / \mathrm{mL}$ pPB114 pPB111 (ITR-P NFATs-mActRIIB $^{\text {ECD }}$-hFC-pA:P RPBSA $^{-}$ EGFP-P2A-ZeoR-pA-ITR) and $50 \mathrm{ng} / \mathrm{mL}$ of the Sleeping Beauty transposase expression vector pCMV-T7-SB100. After selection for two passages with $2.5 \mu \mathrm{g} / \mathrm{mL}$ puromycin and $300 \mu \mathrm{g} / \mathrm{ml} \mathrm{Zeocin,} \mathrm{the} \mathrm{surviving} \mathrm{population} \mathrm{was} \mathrm{FACS-sorted} \mathrm{into} \mathrm{three} \mathrm{different}$ subpopulations based on red-fluorescence and EGFP intensities. The 15\% subpopulation with the highest dTomato and EGFP intensity showed the best performance and was used for following experiments.

The polyclonal hMSC-TERT, Jurkat, HaCaT and BHK-21 cell populations transgenic for stable expression of human TRPM8 and $\mathrm{P}_{\mathrm{NFAT5}}$-SEAP were constructed by co-transfecting cells with pPB112, pPB111 and the Sleeping Beauty transposase expression vector pCMVT7-SB100. After selection for two passages with $2.5 \mu \mathrm{g} / \mathrm{mL}$ puromycin and $300 \mu \mathrm{g} / \mathrm{ml}$ Zeocin, the surviving population was used for the following experiments. 


\section{Live cell $\mathrm{Ca}^{2+}$ imaging.}

Cells were seeded into the optical-bottom of a 24-well plate and transfected as described earlier. Cell imaging was performed using a Nikon TI2 microscope while the cells were maintained in a humidified, $5 \% \mathrm{CO}_{2}$ environmental chamber at $37^{\circ} \mathrm{C}$. A $488 \mathrm{~nm}$ laser was used for GCaMP6s imaging with a 500-550 nm emission filter. During live imaging, $50 \mu \mathrm{l}$ of inducer-containing DMEM was added dropwise into $500 \mu \mathrm{l}$ of medium in each well to achieve final concentrations of $50 \mu \mathrm{M}$ menthol and $10 \mu \mathrm{M}$ oleic acid.

\section{FACS-mediated cell sorting.}

HEK293 cells expressing EGFP (488 nm laser, 530/30 emission filter), BFP (405 nm laser, $450 / 50$ bandpass filter) or dTomato (561 nm laser, 586/15 emission filter) were sorted using a Becton Dickinson LSRII Fortessa flow cytometer (Becton Dickinson, Allschwil, Switzerland) while excluding dead cells and cell doublets. Parental polyclonal populations or untreated HEK293 cells were used as negative controls.

\section{Encapsulation of transgenic cells.}

Alginate-poly-(L-lysine)-alginate microcapsules. Transgenic HEK-293 cells were encapsulated into coherent alginate-poly-(L-lysine)-alginate beads using an Inotech Encapsulator Research Unit IE-50R (EncapBioSystems Inc., Greifensee, Switzerland) with the following settings: $200-\mu \mathrm{m}$ nozzle with a vibration frequency of $1025 \mathrm{~Hz}$, a $25-\mathrm{mL}$ syringe operated at a flow rate of 410 units, and $1.12-\mathrm{kV}$ voltage for bead dispersion. Sodium alginate solution (cat. no. 11061528; Büchi Labortechnik AG, Switzerland) was used for animal experiments related to Fig. 3-5 \& Fig. S3C. Endotoxin-free alginate (PRONOVA UP LVG) (Cat. no. 22363548; NovaMatrix, Norway) dissolved in $0.9 \% \mathrm{NaCl}$ solution $\left(\right.$ Ecotainer $^{\circledR}$ ) (cat. no. 10002362; Braun Melsungen AG, Germany) was used for animal experiments related to Fig. S3A, B \& Fig. S4-7.

Hollow fiber implants. Transgenic HEK-293 cells were seeded into $1.5-\mathrm{cm}$ semi-permeable KrosFlo hollow fiber membranes (Spectrum Laboratories Inc.), and both ends were heatsealed using a smooth needle holder. Implants were cultured in the wells of six-well plates (one $2.5-\mathrm{cm}$ hollow fiber in each well).

Cellulose microcapsules. Transgenic HEK-293 cells were suspended in cellulose sulfate solution $(2 \%(\mathrm{w} / \mathrm{v})$ in PBS; NaCS, Euroferm, Erlangen, Germany, batch-no: CELM-1) and were encapsulated using a standard protocol ${ }^{49}$ and the Inotech Encapsulator Research Unit IE- 
50R (EncapBioSystems Inc., Greifensee, Switzerland) with the following settings: $200 \mu \mathrm{m}$ nozzle with a vibration frequency of $1025 \mathrm{~Hz}, 25 \mathrm{~mL}$ syringe operated at a flow rate of 450 units, voltage for bead dispersion $1.1 \mathrm{kV}$.

\section{Animal experiments.}

Transgene induction in wild-type mice. To test the menthol-controlled transgene expression system in mice, wild-type female OF1 mice (oncins France souche 1, Charles River Laboratories) at 6-8 weeks of age were used and kept in a pathogen-free environment. $1 \times 10^{6}$ stable $\mathrm{Cool}_{\text {Sens }}$ cells were encapsulated into alginate-poly-(L-lysine)-alginate beads and injected into each mouse either intraperitoneally or subcutaneously. After implantation, homemade menthol ointment and commercial products were administered subcutaneously to mice at specific dosages (homemade and Tiger Balm ${ }^{\circledR}$ menthol ointment, $200 \mathrm{mg} / \mathrm{mice}$, twice daily; Salonpas ${ }^{\circledR}$ pain relief patches, $1.5 \mathrm{~cm} \times 1.5 \mathrm{~cm} /$ mouse, once daily; and Eagle ${ }^{\circledR}$ medicated oil, $100 \mu \mathrm{L} /$ mouse, twice daily). To test the influence of environmental changes on the performance of cell implants in vivo, one group of wild-type female OF1 mice was kept at a temperature of $4^{\circ} \mathrm{C}$ for $3 \mathrm{~h}$. Volatile menthol fragrance was released by a Vicks ${ }^{\circledR}$ Waterless Vaporizer containing two Vicks ${ }^{\circledR}$ Vipopads ${ }^{\circledR}$. One group of mice was kept near the vaporizer, and serum SEAP levels were measured after $24 \mathrm{~h}$. To test the influence of food (peppermint oil, peppermint tea) on the performance of cell implants, male C57BL/6 mice (East China Normal University (ECNU) Laboratory Animal Center) were implanted with encapsulated

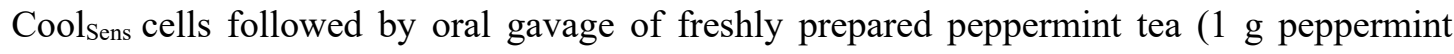
leaves extracted in $10 \mathrm{~mL}$ water; $100 \mu \mathrm{L}$ per day) or diluted peppermint essential oil (1:10 by volume in olive oil; $100 \mu \mathrm{L}$ per day). The effect of temperature change on Coolsens cell activity was further evaluated by exposing male C57BL/6 mice harboring cell capsules either to constant cold temperature $\left(15^{\circ} \mathrm{C}\right)$ or to contact with an ice pack on the skin for $1 \mathrm{~h}$ while under anaesthesia. Blood was collected retro-orbitally.

Alloxan monohydrate/streptozocin-induced diabetic mice. The type-1 diabetic mouse models were generated as described previously ${ }^{50-52}$. In brief, five- to 9-week-old female wild-type, CD-1 Swiss albino mice (Janvier Labs, Le Genest-Saint-Isle, France) or male C57BL/6 mice (Eastern China Normal University (ECNU) Laboratory Animal Center) were fasted for 2 days and received injections of freshly diluted alloxan monohydrate (ALX; a single dose of 200 $\mathrm{mg} / \mathrm{kg}$ in $300 \mu \mathrm{L}$ phosphate-buffered saline) or streptozocin (STZ; five daily doses of 50 $\mathrm{mg} / \mathrm{kg}$ in $100 \mu \mathrm{L}$ of $0.1 \mathrm{M}$ citrate buffer). At 2 days after the final ALX/STZ injection, mice with both persistent fasting hyperglycaemia $(>10 \mathrm{mM})$ and impaired glucose tolerance were considered as type-1 diabetic and selected for $\mathrm{Cool}_{\mathrm{INS}}$ experiments. Implantation was performed by intraperitoneal or subcutaneous injection of $1 \mathrm{~mL}$ of glucose-free DMEM 
containing alginate-poly-(L-lysine)-alginate microencapsulated Cool ${ }_{\mathrm{INS}}$ cells. Tiger Balm ${ }^{\circledR}$ menthol ointment was administered subcutaneously to the mice at specific dosages (200 $\mathrm{mg} / \mathrm{mouse} / \mathrm{dose}$ ). Blood serum was isolated using microtainer serum separating tubes (SST) according to the manufacturer's instructions (centrifugation for $5 \mathrm{~min}$ at $10000 \mathrm{x} \mathrm{g}$; Becton Dickinson, Plymouth, UK; cat. no. 365967).

Dexamethasone (DEX)-induced muscle atrophy mice. Dexamethasone 21-phosphate disodium salt (DEX) was administered to 8-week-old male C57BL/6 mice (Janvier Labs, Le Genest-Saint-Isle, France) via the drinking water at a dose of $2.5 \mathrm{mg} / \mathrm{kg} /$ day for 2 weeks. However, since the administration of DEX caused increased drinking in mice, the concentration of DEX was periodically readjusted in order to maintain the same dosage throughout the treatment. On the first day of dexamethasone administration, mice were subcutaneously injected with $1 \mathrm{~mL}$ of glucose-free DMEM containing $5 \times 10^{6}$ alginate-poly(L-lysine)-alginate microencapsulated stable Cool $_{\text {Sens }}$ and Cool $_{\text {ActRII }}$ cells. Tiger Balm ${ }^{\circledR}$ menthol ointment was administered subcutaneously at specific dosages (twice daily and 2-3 days per week) for 4 weeks ( $200 \mathrm{mg} /$ mouse/dose). At the end of the 4-week treatment, mice were weighed and euthanized. The right triceps surae complex (TS) muscles were excised and weighed. Mice that did not receive DEX-contained drinking water served as negative controls.

Experiments related to Fig. 4-5, Extended Data Figs. 4 B (ii)-C, Extended Data 5 and Extended Data 6C were performed according to the directive of the European Community Council (2010/63/EU), approved by the French Republic and carried out by Ghislaine Charpin-El Hamri (No. 69266309; project No. DR2013-01 (v2)) and Marie Daoud-El Baba (No. 69266310; project No. DR2013-01 (v2)) at the Institut Universitaire de Technologie, UCB Lyon 1, F-696225 Villeurbanne Cedex, France. Experiments related to Extended Data Figs. 4A-B (i), Extended Data 6 Fig. A-B and Extended Data Figs.7-8 were performed in the laboratory of H.Y. according to the protocol (m20190101) approved by the East China Normal University Animal Care and Use Committee and in accordance with the Ministry of Science and Technology of China Guidelines on Animal Care.

Peritoneal lavage. For retrieving cell capsules, $5 \mathrm{~mL}$ of PBS containing 2.5\% FCS was injected into the peritoneal cavity of sacrificed mice. Subsequently, the lavage fluid was retrieved from the peritoneal cavity. Then another $20 \mathrm{~mL}$ of PBS containing $2.5 \%$ FCS was injected into the peritoneal cavity to further wash and recover all the free-floating capsules. To evaluate the extent of pericapsular fibrotic overgrowth (PFO), recovery efficacy was calculated as the percentage of retrievable microcapsules post-transplantation with respect to 
the initial number of implanted cell capsules. Low recovery efficacies are expected to correlate with PFO formation and firm adhesion within the implantation site ${ }^{60}$. In the case of host peritoneal cells, $5 \mathrm{~mL}$ of PBS containing $2.5 \%$ FCS was instilled into the peritoneal cavity of sacrificed animals. Thereafter, the lavage fluid was retrieved from the peritoneal cavity for cell counting and FACS analysis.

Immunostaining and FACS analysis. Spleens harvested from mice were dissociated into single cells using a cell strainer (cat. no. 22363548, Fisher Scientific). Cell suspensions from spleen or peritoneal lavage were centrifuged at $300 \mathrm{~g}$ at $4^{\circ} \mathrm{C}$ and resuspended in $100 \mu \mathrm{l}$ of eBioscience Staining Buffer (cat. no. 00-4222) for antibody incubation. All samples were first incubated with $0.5 \mu 1$ of anti-mouse CD16/32 antibody (TruStain FcX ${ }^{\mathrm{TM}}$ )(cat. no. 101320, lot no. B254979, Biolegend) to block unspecific binding. Samples were then stained in the dark for $25 \mathrm{~min}$ at $4{ }^{\circ} \mathrm{C}$ with fluorescently tagged monoclonal antibodies specific for the cell markers CD11b (1:200 per sample) (CD11b-Alexa-488, Clone M1/70, cat no. 101217, lot no. B254608, BioLegend), CD19 (1:200 per sample) (CD19-Alexa-647, Clone 6D5, cat no. 115522, lot no. B240167, BioLegend), or CD3 (1:200 per sample) (CD3-APC, Clone 1452C11, cat no. 100312, lot no. B260199, BioLegend). $1 \mathrm{ml}$ of eBioscience Flow Cytometry Staining Buffer (cat no. 00-4222, eBioscience) was then added, and the samples were centrifuged at $300 \mathrm{~g}$ for $5 \mathrm{~min}$ at $4^{\circ} \mathrm{C}$. Supernatants were removed by aspiration, and this wash step was repeated two more times with staining buffer. Samples were then suspended in $1 \mathrm{~mL}$ of eBioscience ${ }^{\mathrm{TM}}$ IC fixation buffer (cat. no. 00-8222-49, eBioscience) (for peritoneal cells) or eBioscience ${ }^{\mathrm{TM}} 1$-step Fix/Lyse Solution (for spleen cells), centrifuged and washed twice with staining buffer. Each sample was resuspended in $300 \mu 1$ of Flow Cytometry Staining Buffer for FACS analysis using a BD Fortessa.

\section{Statistical Analysis}

Statistical test and significance are reported in the Figures and corresponding Figure Legends. A two-tailed, unpaired Student's t test and a one-way ANOVA test were applied to determine the statistical significance of differences among groups using Graphpad Prism. Differences are considered statistically significant at $\mathrm{p}<0.05$.

\section{Reporting Summary}

Further information on research design is available in the Nature Research Life Sciences Reporting Summary linked to this article.

\section{Data availability}


The data that support the findings of this study are available on reasonable request to the corresponding author [M.F.].

\section{References (Main Text)}

1. McKemy, D.D., Neuhausser, W.M. \& Julius, D. Identification of a cold receptor reveals a general role for TRP channels in thermosensation. Nature 416, 52-58 (2002).

2. Ausländer, S., Ausländer, D. \& Fussenegger, M. Synthetic Biology—The Synthesis of Biology. Angewandte Chemie International Edition 56, 6396-6419 (2017).

3. Lanitis, E., et al. Redirected antitumor activity of primary human lymphocytes transduced with a fully human anti-mesothelin chimeric receptor. Mol Ther 20, 633643 (2012).

4. Le Guiner, C., Stieger, K., Snyder, R.O., Rolling, F. \& Moullier, P. Immune responses to gene product of inducible promoters. Curr Gene Ther 7, 334-346 (2007).

5. Maus, M.V., et al. $\mathrm{T}$ cells expressing chimeric antigen receptors can cause anaphylaxis in humans. Cancer Immunol Res 1, 26-31 (2013).

6. Anguela, X.M. \& High, K.A. An edible switch for gene therapy. Nature Biotechnology 34, 824 (2016).

7. Nilius, B. \& Szallasi, A. Transient receptor potential channels as drug targets: from the science of basic research to the art of medicine. Pharmacol Rev 66, 676-814 (2014).

8. Zakharian, E., Cao, C. \& Rohacs, T. Gating of transient receptor potential melastatin 8 (TRPM8) channels activated by cold and chemical agonists in planar lipid bilayers. J Neurosci 30, 12526-12534 (2010).

9. Patel, T., Ishiuji, Y. \& Yosipovitch, G. Menthol: a refreshing look at this ancient compound. J Am Acad Dermatol 57, 873-878 (2007).

10. Crabtree, G.R. \& Olson, E.N. NFAT Signaling: Choreographing the Social Lives of Cells. Cell 109, S67-S79 (2002).

11. Xie, M., et al. beta-cell-mimetic designer cells provide closed-loop glycemic control. Science 354, 1296-1301 (2016).

12. Story, G.M., et al. ANKTM1, a TRP-like Channel Expressed in Nociceptive Neurons, Is Activated by Cold Temperatures. Cell 112, 819-829 (2003).

13. Bautista, D.M., et al. The menthol receptor TRPM8 is the principal detector of environmental cold. Nature 448, 204 (2007).

14. Caterina, M.J., et al. The capsaicin receptor: a heat-activated ion channel in the pain pathway. Nature 389, 816 (1997).

15. Asuthkar, S., et al. The TRPM8 protein is a testosterone receptor: II. Functional evidence for an ionotropic effect of testosterone on TRPM8. J Biol Chem 290, 26702688 (2015).

16. Liu, Y., Charpin-El Hamri, G., Ye, H. \& Fussenegger, M. A synthetic free fatty acidregulated transgene switch in mammalian cells and mice. Nucleic acids research $\mathbf{4 6}$, 9864-9874 (2018).

17. Rooney, J.W., Hodge, M.R., McCaffrey, P.G., Rao, A. \& Glimcher, L.H. A common factor regulates both Th1- and Th2-specific cytokine gene expression. The EMBO journal 13, 625-633 (1994).

18. Berridge, M.J., Bootman, M.D. \& Roderick, H.L. Calcium signalling: dynamics, homeostasis and remodelling. Nat Rev Mol Cell Biol 4, 517-529 (2003). 
19. Crabtree, G.R. \& Schreiber, S.L. SnapShot: Ca2+-calcineurin-NFAT signaling. Cell 138, 210, 210 e211 (2009).

20. Muller, M.R. \& Rao, A. NFAT, immunity and cancer: a transcription factor comes of age. Nat Rev Immunol 10, 645-656 (2010).

21. Orive, G., et al. Cell encapsulation: technical and clinical advances. Trends Pharmacol Sci 36, 537-546 (2015).

22. Jacobs-Tulleneers-Thevissen, D., et al. Sustained function of alginate-encapsulated human islet cell implants in the peritoneal cavity of mice leading to a pilot study in a type 1 diabetic patient. Diabetologia 56, 1605-1614 (2013).

23. Vaithilingam, V., et al. Characterisation of the Xenogeneic Immune Response to Microencapsulated Fetal Pig Islet-Like Cell Clusters Transplanted into Immunocompetent C57BL/6 Mice. PLOS ONE 8, e59120 (2013).

24. Vegas, A.J., et al. Long-term glycemic control using polymer-encapsulated human stem cell-derived beta cells in immune-competent mice. Nature Medicine 22, 306 (2016).

25. Zakrzewski, J.L., van den Brink, M.R. \& Hubbell, J.A. Overcoming immunological barriers in regenerative medicine. Nat Biotechnol 32, 786-794 (2014).

26. Zekorn, T.D.C., et al. Evidence for an antigen-release induced cellular immune response against alginate-polylysine encapsulated islets. Xenotransplantation 2, 116119 (1995).

27. Johnson, J.D. The quest to make fully functional human pancreatic beta cells from embryonic stem cells: climbing a mountain in the clouds. Diabetologia 59, 20472057 (2016).

28. Lecker, S.H., Goldberg, A.L. \& Mitch, W.E. Protein degradation by the ubiquitinproteasome pathway in normal and disease states. J Am Soc Nephrol 17, 1807-1819 (2006).

29. Williams, G.R., Muss, H.B. \& Shachar, S.S. Cachexia in patients with cancer. Lancet Oncol 17, e220 (2016).

30. Hq Han, X.Z. Novel hybrid actriib ligand trap proteins for treating muscle wasting diseases. . EP3286206A1 2015-04-22.

31. Zhou, X., et al. Reversal of cancer cachexia and muscle wasting by ActRIIB antagonism leads to prolonged survival. Cell 142, 531-543 (2010).

32. Lach-Trifilieff, E., et al. An antibody blocking activin type II receptors induces strong skeletal muscle hypertrophy and protects from atrophy. Mol Cell Biol 34, 606618 (2014).

33. Kaufmann, K.B., Buning, H., Galy, A., Schambach, A. \& Grez, M. Gene therapy on the move. EMBO Mol Med 5, 1642-1661 (2013).

34. Orive, G., et al. History, challenges and perspectives of cell microencapsulation. Trends Biotechnol 22, 87-92 (2004).

35. Fischbach, M.A., Bluestone, J.A. \& Lim, W.A. Cell-based therapeutics: the next pillar of medicine. Sci Transl Med 5, 179ps177 (2013).

36. Kobayashi, T., et al. Immune mechanisms associated with the rejection of encapsulated neonatal porcine islet xenografts. Xenotransplantation 13, 547-559 (2006).

37. Bai, P., et al. A synthetic biology-based device prevents liver injury in mice. $J$ Hepatol 65, 84-94 (2016).

38. Schukur, L., Geering, B., Charpin-El Hamri, G. \& Fussenegger, M. Implantable synthetic cytokine converter cells with AND-gate logic treat experimental psoriasis. Sci Transl Med 7, 318ra201 (2015).

39. Wang, H., Xie, M., Charpin-El Hamri, G., Ye, H. \& Fussenegger, M. Treatment of chronic pain by designer cells controlled by spearmint aromatherapy. Nature Biomedical Engineering 2, 114-123 (2018).

40. Ye, H., Daoud-El Baba, M., Peng, R.W. \& Fussenegger, M. A synthetic optogenetic transcription device enhances blood-glucose homeostasis in mice. Science 332, 15651568 (2011). 


\section{References (Methods)}

41. Boukamp, P., et al. Normal keratinization in a spontaneously immortalized aneuploid human keratinocyte cell line. J Cell Biol 106, 761-771 (1988).

42. Simonsen, J.L., et al. Telomerase expression extends the proliferative life-span and maintains the osteogenic potential of human bone marrow stromal cells. Nat Biotechnol 20, 592-596 (2002).

43. Heng, B.C., et al. mRNA transfection-based, feeder-free, induced pluripotent stem cells derived from adipose tissue of a 50-year-old patient. Metab Eng 18, 9-24 (2013).

44. Wieland, M., Auslander, D. \& Fussenegger, M. Engineering of ribozyme-based riboswitches for mammalian cells. Methods 56, 351-357 (2012).

45. Berger, J., Hauber, J., Hauber, R., Geiger, R. \& Cullen, B.R. Secreted placental alkaline phosphatase: a powerful new quantitative indicator of gene expression in eukaryotic cells. Gene 66, 1-10 (1988).

46. Schlatter, S., Rimann, M., Kelm, J. \& Fussenegger, M. SAMY, a novel mammalian reporter gene derived from Bacillus stearothermophilus alpha-amylase. Gene 282, 1931 (2002).

47. Schmittgen, T.D. \& Livak, K.J. Analyzing real-time PCR data by the comparative CT method. Nature Protocols 3, 1101 (2008).

48. Mates, L., et al. Molecular evolution of a novel hyperactive Sleeping Beauty transposase enables robust stable gene transfer in vertebrates. Nat Genet 41, 753-761 (2009).

49. Fluri, D.A., Kemmer, C., Daoud-El Baba, M. \& Fussenegger, M. A novel system for trigger-controlled drug release from polymer capsules. J Control Release 131, 211219 (2008).

50. Auslander, D., et al. A synthetic multifunctional mammalian $\mathrm{pH}$ sensor and $\mathrm{CO} 2$ transgene-control device. Mol Cell 55, 397-408 (2014).

51. Shao, J., et al. Smartphone-controlled optogenetically engineered cells enable semiautomatic glucose homeostasis in diabetic mice. Sci Transl Med 9(2017).

52. Fritschy, W.M., et al. The capsular overgrowth on microencapsulated pancreatic islet grafts in streptozotocin and autoimmune diabetic rats. Transpl Int 7, 264-271 (1994).

\section{Figure legends}

Figure 1. Design of a cooling sensation-regulated transgene switch. (A) Schematic diagram. Activation of the human TRPM8 channel allows cations to pass through the membrane and triggers in an increase of intracellular calcium. This increase leads to nuclear translocation of calcium-responsive transcription factors such as nuclear factors of activated T-cells (NFAT), enabling NFAT to bind specific promoters $\left(\mathrm{P}_{\mathrm{NFAT} 3}\right)$ and induce transgene expression. (B) SEAP levels (in enzyme units per liter) in culture supernatants of HEK-293 cells co-transfected with a plasmid encoding an NFAT-dependent SEAP reporter construct ( $\mathrm{P}_{\mathrm{NFAT3}}$-SEAP-pA) and plasmids encoding hTRPM8 ( $\left.\mathrm{P}_{\mathrm{hCMV}}-\mathrm{hTRPM} 8-\mathrm{pA}\right)$, hTRPV1 ( $\mathrm{P}_{\mathrm{hCMV}}{ }^{-}$ hTRPV1-pA) or hTRPA1 ( $\mathrm{P}_{\mathrm{hCMv}}$-hTRPA1-pA). Cells were stimulated with specific channel agonists (menthol, $100 \mu \mathrm{M}, 24 \mathrm{~h}$; capsaicin, $0.1 \mu \mathrm{M}, 1 \mathrm{~h}$; or cinnamaldehyde, $50 \mu \mathrm{M}, 3 \mathrm{~h}$ ) or by exposure to the indicated temperatures. SEAP levels were measured $24 \mathrm{~h}$ after stimulation. Data presented are means $\pm \mathrm{SD}, \mathrm{n}=3$ biologically independent samples. (C) SEAP levels (in enzyme units per liter) in culture supernatants of HEK-293 cells co-transfected with a plasmid 
encoding hTRPM8 ( $\mathrm{P}_{\mathrm{hCMV}}$-hTRPM8-pA) and reporter plasmids encoding different calcium-

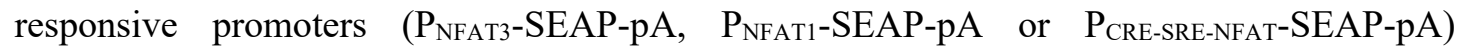
following 24-h cultivation in culture medium containing $0 \mu \mathrm{M}$ or $100 \mu \mathrm{M}$ menthol. Data presented are means $\pm \mathrm{SD}, \mathrm{n}=3$ biologically independent samples. The fold-changes are indicated above the bars.

Figure 2. Characterization of the Cool $_{\text {Sens }}$ gene switch in cells. (A) SEAP levels in culture supernatants of HEK-293, hMSC-TERT, Jurkat, HacaT, BHK-21 and patient-derived primary MSC cells co-transfected with an NFAT-dependent reporter plasmid ( $\mathrm{P}_{\mathrm{NFAT5}}-\mathrm{SEAP}-\mathrm{pA}$ ) and a constitutive hTRPM8-expression plasmid ( $\left.\mathrm{P}_{\mathrm{EF} 1 \alpha}-\mathrm{hTRPM} 8-\mathrm{pA}\right)$. SEAP levels were measured $24 \mathrm{~h}$ after treatment without or with $50 \mu \mathrm{M}$ menthol. Data presented are means $\pm \mathrm{SD}, \mathrm{n}=5$ biologically independent samples. $P$ values were determined using a two-tailed $t$ test. Foldchanges are indicated above the bars. (B) SEAP levels in culture supernatants of HEK-293 cells co-transfected with an NFAT-dependent reporter plasmid (PNFAT3-SEAP-pA) and a constitutive hTRPM8-expression plasmid ( $\mathrm{P}_{\mathrm{hCMv}}$-hTRPM8-pA) or a EYFP-expression plasmid (mock control). Cells were treated with the indicated menthol concentrations for $24 \mathrm{~h}$. Data presented are means $\pm \mathrm{SD}, \mathrm{n}=3$ biologically independent samples. (C) SEAP levels in culture supernatants of HEK-293 cells co-transfected with an NFAT-dependent reporter plasmid ( $\left.\mathrm{P}_{\mathrm{NFAT3}}-\mathrm{SEAP-pA}\right)$ and a constitutive hTRPM8-expression plasmid ( $\mathrm{P}_{\mathrm{hCMV}}-\mathrm{hTRPM8-}$ pA). Cells were incubated with $100 \mu \mathrm{M}$ menthol for the indicated periods of time $(0,0.5,1,2$, 3 or $6 \mathrm{~h}$ ) before the culture medium was changed to menthol-free medium, and the cells were further cultured, with total culture times of 12, 24 or $48 \mathrm{~h}$. Data presented are means $\pm \mathrm{SD}$, $\mathrm{n}=3$ biologically independent samples. (D) SEAP levels in culture supernatants of Coolsens-

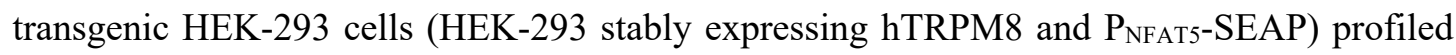
at the indicated time points following treatment with or without $50 \mu \mathrm{M}$ menthol. Data presented are means $\pm \mathrm{SD}, \mathrm{n}=3$ biologically independent samples. (E) SEAP levels in culture supernatants of Coolsens-transgenic HEK-293 cells cultivated in the two indicated schemes in which the presence $(\mathrm{ON})$ and absence (OFF) of menthol was alternated for five 24-h intervals. OFF: Cool $_{\text {sens }}$ cells $\left(2 \times 10^{5}\right.$ cells per $\left.\mathrm{ml}\right)$ permanently cultivated in menthol-free medium during each interval. ON: The cell density was readjusted to $2 \times 10^{5}$ cells per ml prior to stimulation with $50 \mu \mathrm{M}$ menthol during the first $3 \mathrm{~h}$ of each interval. Data presented are means \pm SD, $n=3$ biologically independent samples. (F) SEAP levels in culture supernatants of Coolsens-transgenic HEK-293 cells cultivated for $24 \mathrm{~h}$ in standard culture medium (normal) or culture medium containing high $(20 \mathrm{mM})$ lactic acid, low $(1 \mathrm{mM})$ glucose or $100 \mu \mathrm{M}$ $\mathrm{CoCl}_{2}$ (a hypoxia-mimetic agent). Cells were treated with or without $50 \mu \mathrm{M}$ menthol. Data presented are means $\pm \mathrm{SD}, \mathrm{n}=3$ biologically independent samples. (G) SEAP levels in culture supernatants of Coolsens-transgenic HEK-293 cells transfected with plasmids encoding human 
GPR40, human TGR5 or human TLR2/human CD14. Coolsens-transgenic HEK-293 cells transfected with pcDNA3.1(+) were used as a reference for full functionality of the gene switch. Cells were cultivated for $24 \mathrm{~h}$ with culture medium supplemented with menthol and/or their respective agonists (GPR40, $10 \mu \mathrm{M}$ oleic acid; TGR5, $100 \mu \mathrm{M}$ cholic acid; TLR2, 10 $\mathrm{ng} / \mathrm{ml} \mathrm{S}$. aureus peptidoglycan), or without either menthol or agonist. Data presented are means $\pm \mathrm{SD}, \mathrm{n}=3$ biologically independent samples.

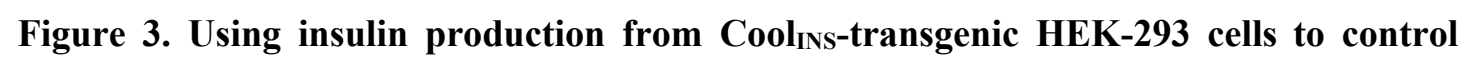
blood glucose homeostasis in a type 1 diabetic mice model. (A, B) Serum SEAP levels in wild-type mice implanted subcutaneously (A) or intraperitoneally (B) with encapsulated

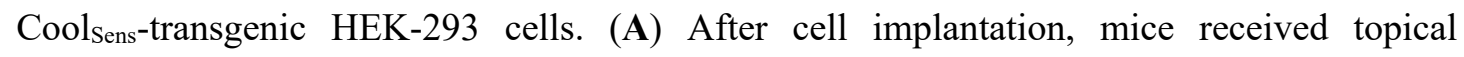
application of homemade menthol ointments (containing $0.3 \mathrm{M}$ or $0.9 \mathrm{M}$ menthol, 200 $\mathrm{mg} /$ mouse, $\mathrm{n}=6$ ) or menthol-containing commercial products (Tiger Balm ${ }^{\circledR}$ menthol ointment $(\sim 0.6 \mathrm{M}, 200 \mathrm{mg} /$ mouse, $\mathrm{n}=6)$, Salonpas ${ }^{\circledR}$ menthol patch $(\sim 0.34 \mathrm{M}, 1.5 \mathrm{~cm} \times 1.5 \mathrm{~cm}$ patch per mouse, $\mathrm{n}=6)$ or Eagle ${ }^{\circledR}$ medicated oil $(1.7 \mathrm{M}, 100 \mu \mathrm{L}$ per mouse, $\left.\mathrm{n}=6)\right)$. Control mice received menthol-free ointments (olive oil/vaseline mixture 1:1, $\mathrm{n}=12$ ). (B) After cell implantation, mice received oral administration of homemade menthol-containing liquid (containing 0.03 $\mathrm{M}(\mathrm{n}=6), 0.15 \mathrm{M}(\mathrm{n}=6)$ or $0.3 \mathrm{M}(\mathrm{n}=5)$ menthol, $100 \mu \mathrm{L} /$ mouse). Control mice received olive oil $(n=12)$. SEAP levels in the bloodstream of mice were measured at $24 \mathrm{~h}$ after implantation. Each dot represents an individual mouse. $P$ values of each treatment condition were determined using a two-tailed $t$ test versus the control group. (C-F) 9-day glycemic control in

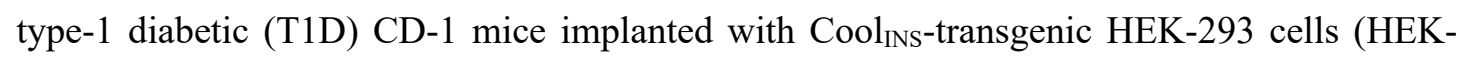

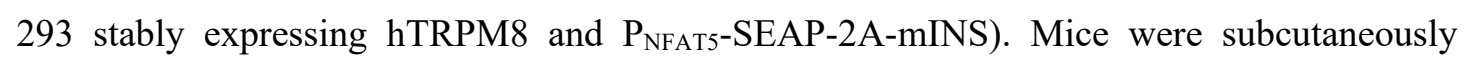
implanted with $5 \times 10^{6} \mathrm{Cool}_{\mathrm{INS}}$-transgenic HEK-293 cells and topical menthol ointments were applied twice daily. Non-diabetic control mice received no treatment. $P$ values were

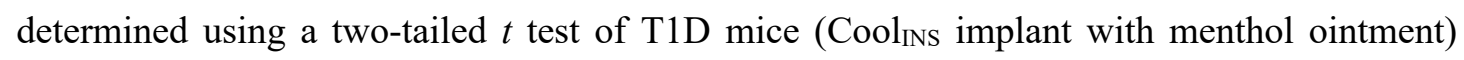
versus the negative control group (Cool INS implant without menthol ointment). (C) Fasting blood glucose levels at the indicated days after cell implantation. Data are shown as means \pm SEM ( $n=6$ mice per group). (D) Blood insulin levels of the same mice as (C) profiled at day 2. Each dot represents an individual mouse ( $n=6$ mice per group). (E and $\mathbf{F})$ Intraperitoneal glucose tolerance tests (GTTs) performed on day 2 (E) and day 9 (F) after cell implantation. Data are shown as means \pm SEM ( $n=6$ mice per group). (G) Blood SEAP levels of T1D-

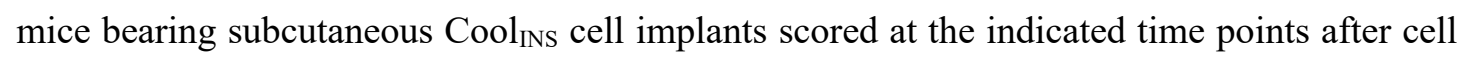
implantation. Menthol was topically applied on day 4, removed on day 7 and re-applied on day $9((+)-(-)-(+))$. T1D mice receiving Cool $_{\text {INS }}$ cell implants but no menthol application were used as negative control $((-)-(-)-(-))$. Each dot represents an individual mouse $(n=6$ mice per group). (H) Blood glucose levels in the T1D mice receiving menthol treatment in 
(G). $P$ values were determined using a two-tailed $t$ test between indicated datasets. NS, not significant.

Figure 4. Therapeutic efficacy of an ActRIIB trap protein produced from Cool $_{\text {ActRII- }}$ transgenic HEK-293 cells in mice with dexamethasone-induced muscle atrophy. (A) mActRIIB $^{\mathrm{ECD}}$-hFC levels in cell culture medium of HEK-293 cells co-transfected with a constitutive hTRPM8-expression plasmid ( $\mathrm{P}_{\mathrm{EF} 1 \alpha}-\mathrm{hTRPM} 8-\mathrm{pA}$ ) and a plasmid providing NFAT-dependent expression of an ActRIIB trap protein $\left(\mathrm{P}_{\mathrm{NFAT5}}-\mathrm{mActRIIB}{ }^{\mathrm{ECD}}\right.$-hFC-pA). Cells were cultivated for $24 \mathrm{~h}$ in medium supplemented with or without $50 \mu \mathrm{M}$ menthol. Data presented are means $\pm \mathrm{SD}, \mathrm{n}=3$ biologically independent samples. (B) Left, luciferase

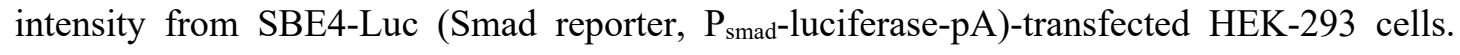
Cells were incubated with myostatin and conditioned media from control cells (pPB111/pPB112-transgenic HEK-293 cells with $50 \mu \mathrm{M}$ menthol), induced cells (pPB112/pPB114-transgenic HEK-293 cells with $50 \mu \mathrm{M}$ menthol) and non-induced cells (pPB112/pPB114-transgenic HEK-293 cells without menthol) for $24 \mathrm{~h}$ before quantifying luciferase production. Data presented are mean $\pm \mathrm{SD}, \mathrm{n}=4$ biologically independent samples. Right, schematic indicating that $\mathrm{mActRIIB}^{\mathrm{ECD}}-\mathrm{hFC}$ binding to myostatin inhibits myostatinmediated signaling activation of the activin type IIB receptor. (C) Serum mActRIIB ${ }^{\mathrm{ECD}}-\mathrm{hFC}$ levels in dexamethasone-treated mice with or without topical menthol ointment application (twice per day, first administration at $3 \mathrm{~h}$ after cell implantation), measured at day 2 after implantation with Cool $_{\text {ActRII }}$ cells. Each dot represents an individual mouse $(\mathrm{n}=6$ mice per group). $P$ values were determined using a two-tailed $t$ test between indicated datasets. (D) Body-weight changes in mice receiving subcutaneous implantation of control cells (Cool $1_{\text {sens, }}$, pPB111/pPB112 transgenic cells) or $\mathrm{Cool}_{\text {ActRII }}$ cells with or without topical menthol applications (twice per day). WT denotes wild-type mice not receiving any treatment. Changes in body weight were calculated as the ratios of body-weight change on day 21 to the initial weight on day 1. Each dot represents an individual mouse (WT group, $n=7$ mice; Cool $_{\text {sens }}$ groups, $\mathrm{n}=8$; Cool $_{\text {ActRII }}$ groups, $\mathrm{n}=6$ ). $P$ values were determined using a two-tailed $t$ test between indicated datasets. NS, not significant. (E) Changes in triceps surae complex (TS) muscle weight in the indicated groups of mice were calculated as the difference between the mean value of wild-type control mice and that of mice bearing cell implants and treated with menthol. Each dot represents an individual mouse (WT group, $\mathrm{n}=7$ mice; Cool ${ }_{\text {sens }}$ groups, $\mathrm{n}=8$; Cool $_{\text {ActRII }}$ groups, $\mathrm{n}=6$ ). $P$ values were determined using a two-tailed $t$ test between indicated datasets. NS, not significant. (F) Representative pictures of mice from the control group ( $\mathrm{Cool}_{\text {Sens }}$ without menthol) and the treatment group ( $\mathrm{Cool}_{\mathrm{ActRII}}$ with menthol), as described in (D). 
a

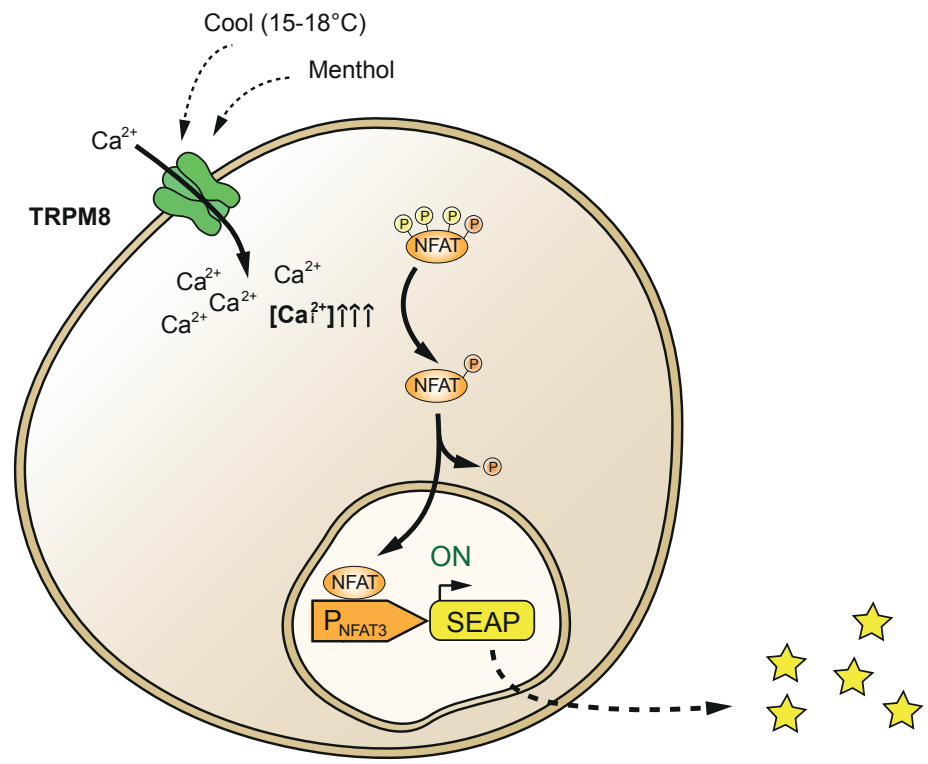

b

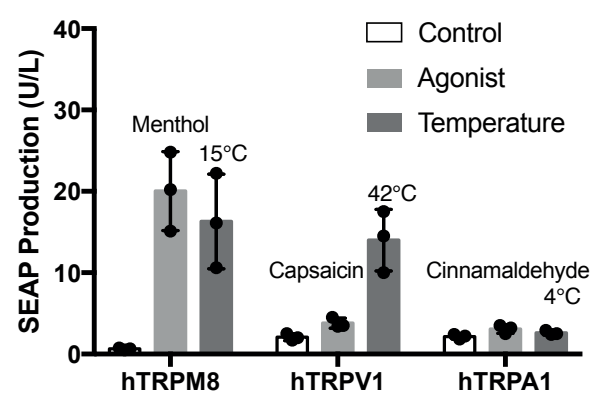

C

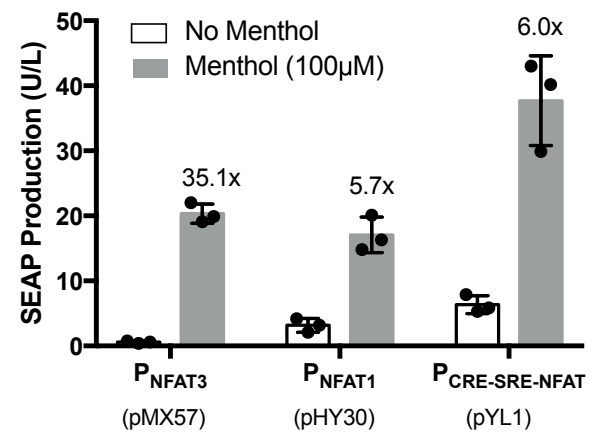



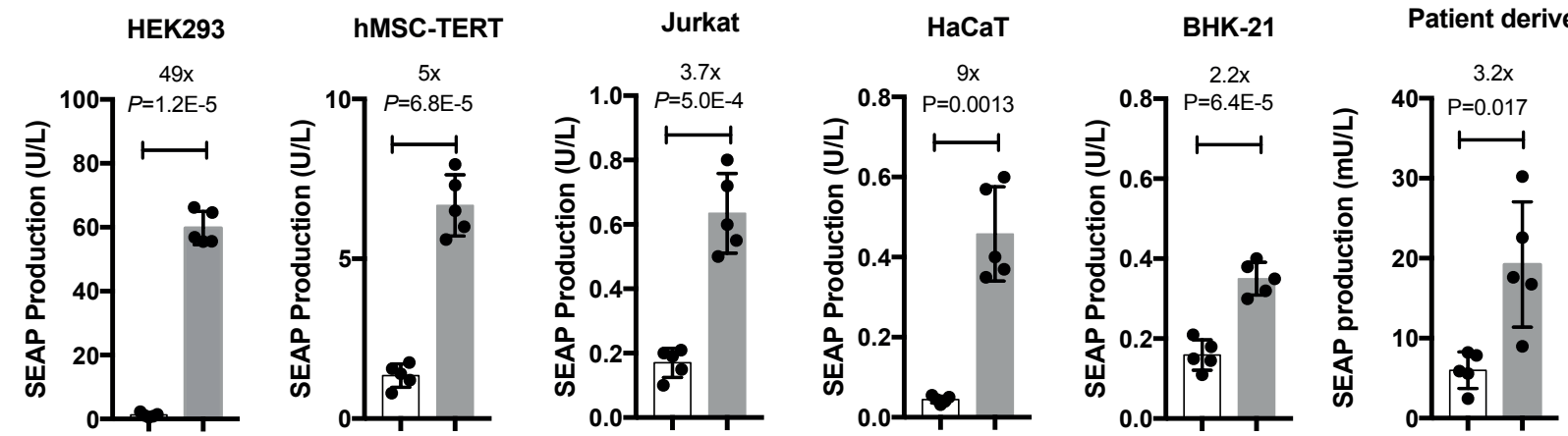

b

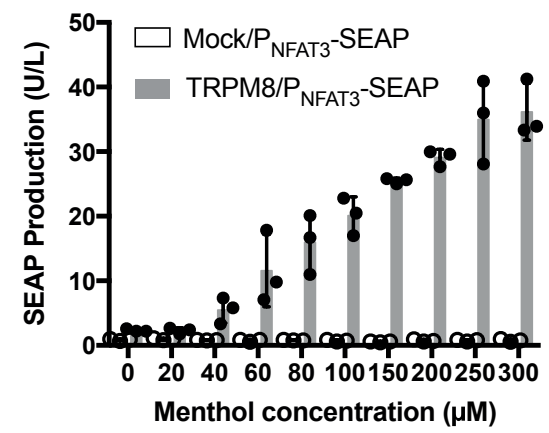

d

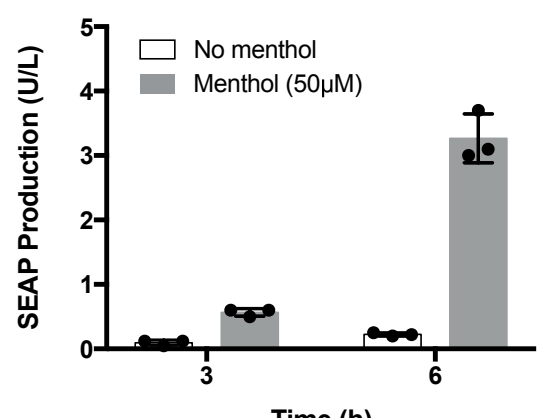

Time (h)

f

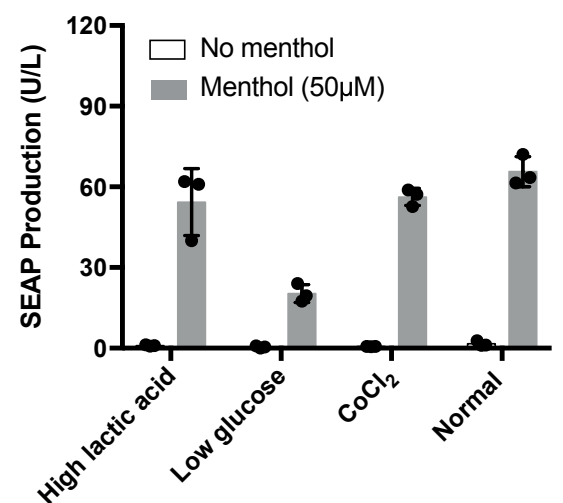

C

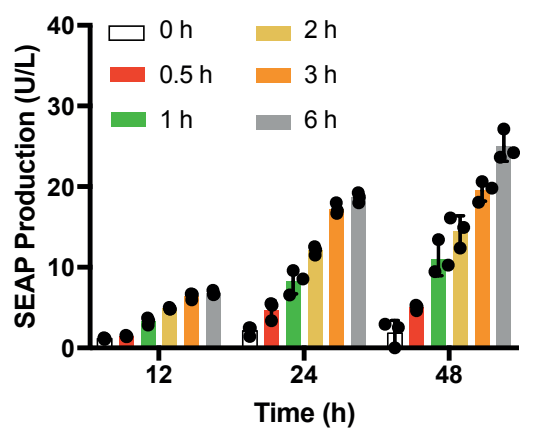

e

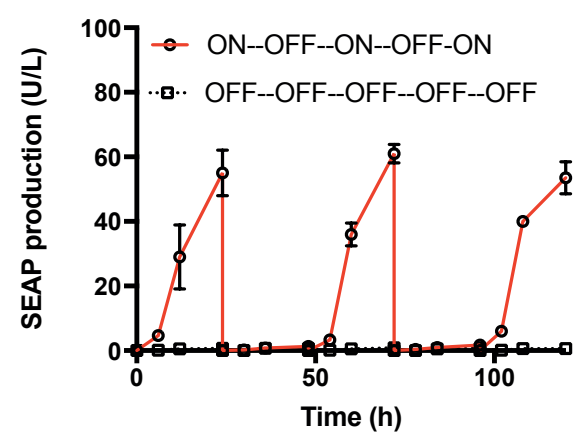

g

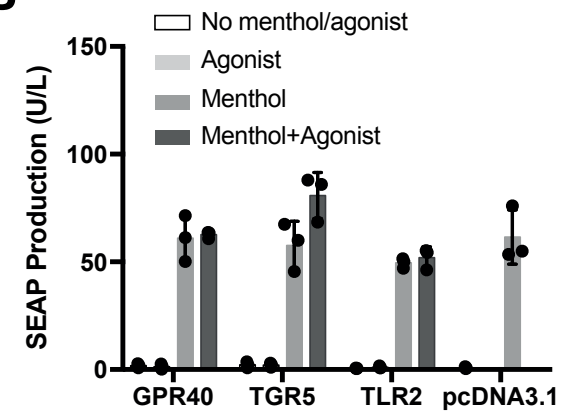



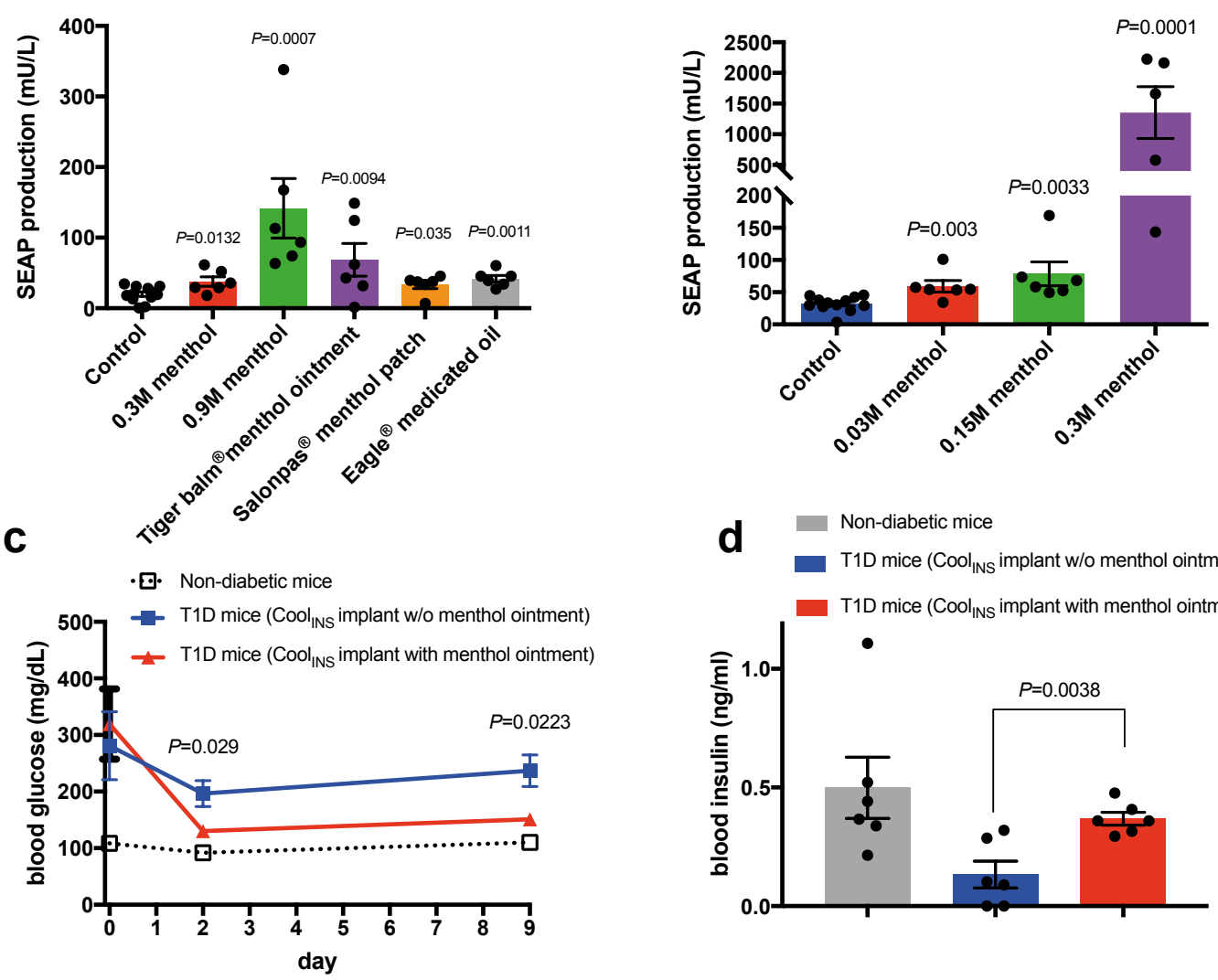

e
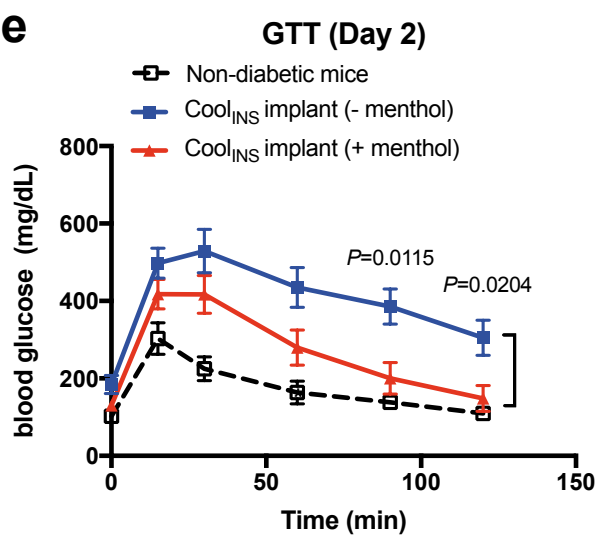

9
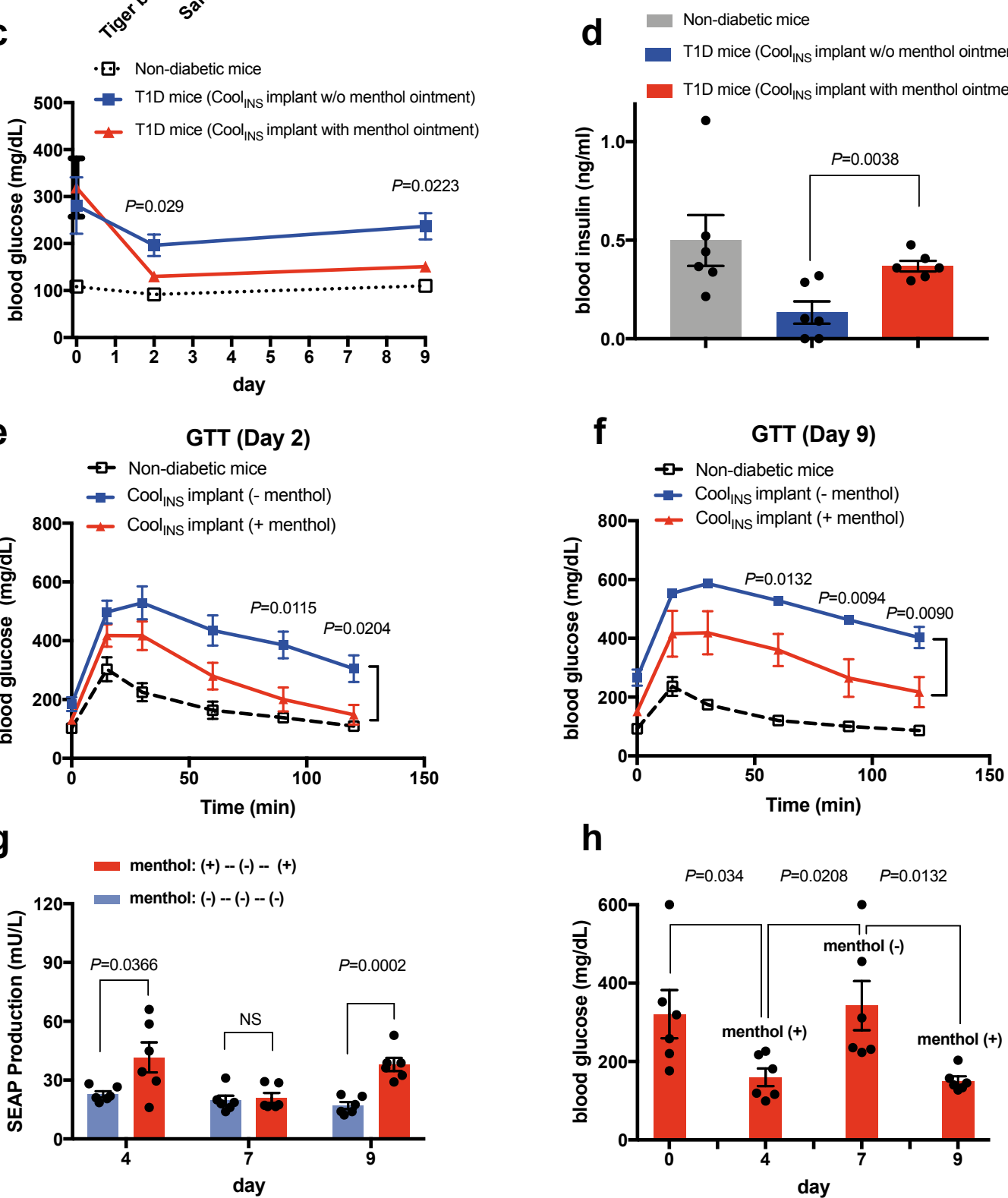

h

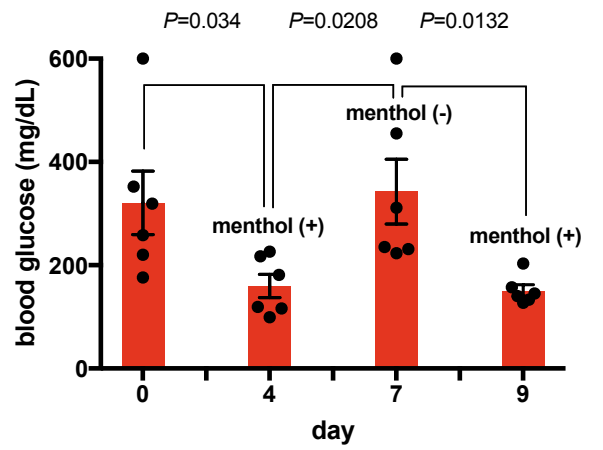

Figure 3 

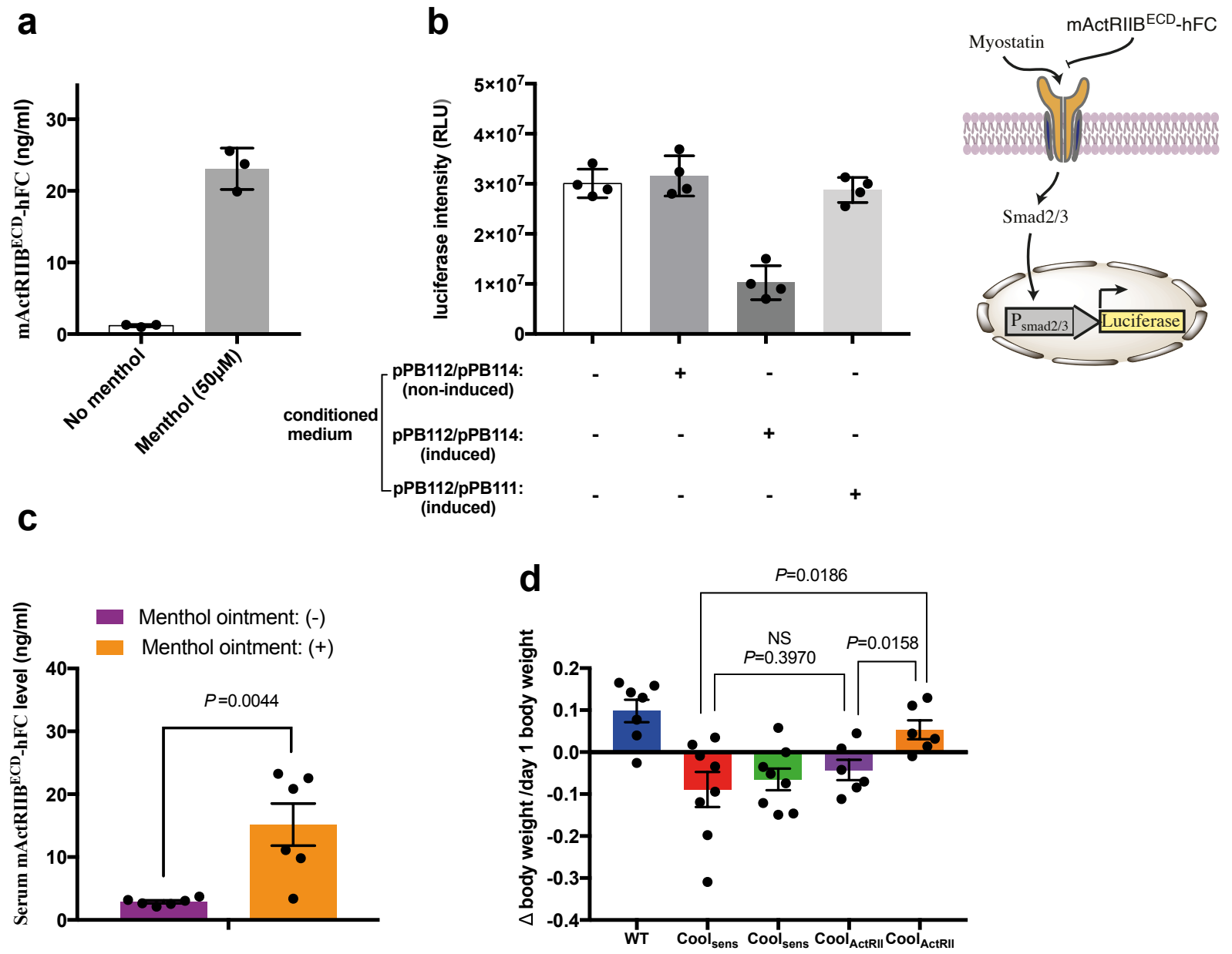

Menthol ointment: $\quad-\quad+\quad+\quad+\quad+$

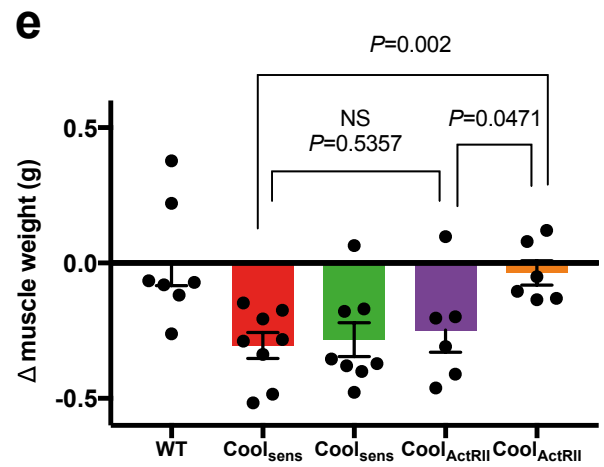

Menthol ointment:

$+\quad-\quad+$

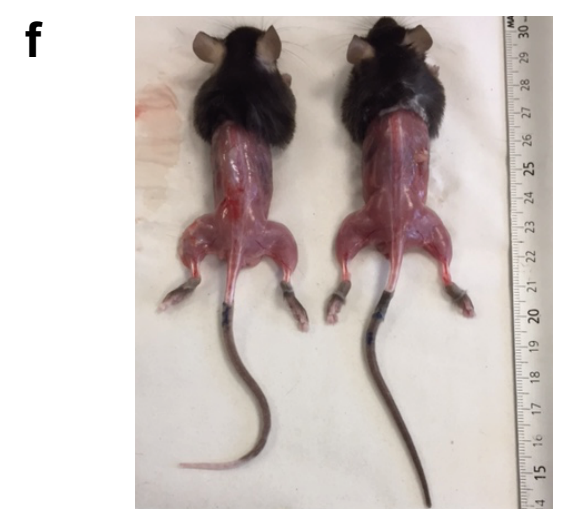

Control Treatment 


\section{Extended data}

\section{Extended Data Fig. 1 Functional characterization of Coolsens gene switch in vitro}

a, Menthol-inducible NFAT translocation on hTRPM8 activation demonstrated with micrographs of both HEK-293 cells cotransfected with HA-NFAT1(4-460)-GFP (P $\mathrm{hCMV}^{-}$ NFAT1(4-460)-GFP-pA) and pPB112 ( $\left.\mathrm{P}_{\mathrm{hEF} 1 \alpha}-h T R P M 8-\mathrm{pA}\right)$, and cultivated for $1 \mathrm{~h}$ in the absence or presence of $100 \mu \mathrm{M}$ menthol. Differences between the images are highlighted by arrows. From left to right: phase contrast, fluorescence and overlaid microscope images. The experiments were repeated independently at least three times with similar results. b, Ciclosporin-mediated inhibition of menthol-induced transgene expression demonstrated with SEAP levels in culture supernatants of pPB112/pPB111-transgenic HEK-293 cells induced by menthol $(50 \mu \mathrm{M})$ and cultivated for $24 \mathrm{~h}$ in the presence or absence of ciclosporin. Data presented are mean \pm s.d.; $n=3$ biologically independent samples. c, SEAP levels in culture supernatants of pPB112/pPB111-transgenic HEK-293 cells cultivated for $24 \mathrm{~h}$ in medium containing menthol esters (i), menthol derivatives (ii) or monoterpenes (iii) with a mint-like flavor and capsaicin. Data presented are mean \pm s.d.; $n=3$ biologically independent samples. d, SEAP levels in culture supernatants of pPB112/pPB111-transgenic HEK-293 cells cultivated for $24 \mathrm{~h}$ in medium containing testosterone or menthol. Data presented are mean \pm s.d.; $n=3$ biologically independent samples. e, SEAP levels in culture supernatants of

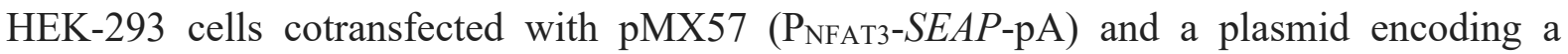
constitutive expression unit for TRPM8 of human, rat or murine origin, cultivated for $24 \mathrm{~h}$ in the presence of $100 \mu \mathrm{M}$ menthol. Data presented are mean \pm s.d.; $n=3$ biologically independent samples. f, SEAP levels in culture supernatants of a mixed population between phTRPM8/pMX57-transgenic HEK-293 cells and pPB108/pMX57-transgenic HEK-293 cells cultivated for $24 \mathrm{~h}$ at $37^{\circ} \mathrm{C}$ following a 1 -h stimulation time at $18{ }^{\circ} \mathrm{C}$ or $42^{\circ} \mathrm{C}$. Control cells were kept constantly at $37^{\circ} \mathrm{C}$. Data presented are mean \pm s.d.; $n=3$ biologically independent samples. g, SEAP levels in culture supernatants of pPB112/pPB111-transgenic HEK-293 cells cultivated for $24 \mathrm{~h}$ in menthol-free medium after a pre-stimulation with $50 \mu \mathrm{M}$ menthol for different time periods and subsequent medium exchange. Data presented are mean \pm s.d.; $n=3$ biologically independent samples.

\section{Extended Data Fig. 2 Orthogonality of Coolsens in vitro}

a, SEAP levels in culture supernatants of HEK-293 cells transfected with plasmids encoding hGPR40 (PhCMv-hGPR40-FLAG-pA), human phTRPM8 (PhCMv-hTRPM8-pA) and pMX57 ( $\left.\mathrm{P}_{\mathrm{NFAT}}-S E A P-\mathrm{pA}\right)$, and cultivated for $24 \mathrm{~h}$ with the respective agonist of each receptor (oleic acid $10 \mu \mathrm{M}, 50 \mu \mathrm{M}$; menthol, $50 \mu \mathrm{M}$ ). Data presented are mean \pm s.d.; $n=3$ biologically independent samples. b, SEAP levels in culture supernatants of HEK-293 cells transfected with plasmids encoding human GPR40 ( $\left.\mathrm{P}_{\mathrm{hCMV}}-h G P R 40-F L A G-\mathrm{pA}\right)$, human phTRPM8 ( $\mathrm{P}_{\mathrm{hCMV}}-$ hTRPM8-pA) and pYL1 (P PRE-SRE-NFAT-SEAP-pA), and cultivated for $24 \mathrm{~h}$ with the respective agonist of each receptor (oleic acid $10 \mu \mathrm{M}$; menthol, $50 \mu \mathrm{M}$ ). Data presented are mean \pm s.d.; $n=3$ biologically independent samples. c, Insensitivity of Coolsens to endogenous NFAT agonists demonstrated with SEAP levels in culture supernatants of pPB112/pPB111transgenic HEK-293 cells cultivated for $48 \mathrm{~h}$ in medium supplemented with different NFAT 
agonists at bioactive concentrations $\left(\operatorname{VEGF}_{165}\left(40 \mathrm{ng} \mathrm{m}^{-1}\right)\right.$, insulin $\left(100 \mathrm{ng} \mathrm{m}^{-1}\right)$, angiotensin II $(1 \mu \mathrm{M})$, L-norepinephrine $(100 \mu \mathrm{M})$, acetylcholine $(2 \mathrm{mM})$ and IL-6 $\left(1 \mathrm{ng} \mathrm{ml}^{-1}\right)$. KCl, $20 \mathrm{mM}$, was used as a positive control. Data presented are mean \pm s.d.; $n=3$ biologically independent samples. d, Relative expression levels of representative NFAT-target genes (see Supplementary Table 2) in Coolsens cells after menthol-triggered activation determined with RT-qPCR. HEK-293 cells, Coolsens cells stimulated by menthol for 1 week or Coolsens cells stimulated by menthol for 5 weeks were harvested for RNA extraction. Data presented are mean \pm s.d.; $n=3$ biologically independent samples.

\section{Extended Data Fig. 3 Functionality of Cool $_{\text {Sens }}$ gene switch in encapsulated cells}

a, Stable HEK-293-derived Cool $_{\text {Sens }}$ cells were encapsulated into alginate-poly(L-lysine)alginate microcapsules and cultivated in six-well plates $\left(\sim 5 \times 10^{5}\right.$ cells per well). SEAP expression in the culture supernatants was profiled at $24 \mathrm{~h}$ after the addition of menthol $(50 \mu \mathrm{M})$. All the data are shown as mean \pm s.d.; $n=3$ independent experiments. b, Stable HEK293-derived Coolsens cells were encapsulated into hollow-fiber macrocapsules and cultivated in six-well plates $\left(\sim 1 \times 10^{5}\right.$ cells per well). SEAP expression in the culture supernatants was profiled at $24 \mathrm{~h}$ after coculturing with menthol $(50 \mu \mathrm{M})$. All data are shown as mean \pm s.d.; $n=4$ biologically independent samples. c, Stable HEK-293-derived Cool Sens $_{\text {s }}$ cells were encapsulated into cellulose microcapsules and cultivated in six-well plates $\left(\sim 5 \times 10^{5}\right.$ cells per well). SEAP expression in the culture supernatants was profiled after $24 \mathrm{~h}$ in the presence of menthol $(50 \mu \mathrm{M})$. All data are shown as mean \pm s.d. $; n=3$ independent experiments. $P$ values were determined using a two-tailed, Student's $t$-test.

\section{Extended Data Fig. 4 Orthogonality of Coolsens in vivo}

a, Effect of typical menthol-containing foods on transgene expression in mice demonstrated with 24-h SEAP levels in the bloodstream of mice harboring intraperitoneal Coolsens implants $\left(2 \times 10^{6}\right.$ cells per mouse $)$ and receiving oral administrations of freshly prepared peppermint tea (100 $\mu 1$ of $10 \mathrm{ml}$ water containing $1 \mathrm{~g}$ dry peppermint leaves), peppermint essential oil (100 $\mu 1$ of 1:10 dilution in olive oil) or menthol ( $0.3 \mathrm{M}$ in olive oil) (positive control). Data are shown as mean \pm s.e.m.; $n=5$, each dot representing an individual mouse. Statistics by one-way ANOVA test. b, Effect of cold exposure on transgene expression in mice demonstrated with 24-h SEAP levels in the bloodstream of mice harboring subcutaneous Coolsens implants $\left(2 \times 10^{6}\right.$ cells per mouse) and either (i) kept at room temperature (room temperature, $\left.n=6\right)$, in a room with constant temperature control at $15^{\circ} \mathrm{C}\left(15^{\circ} \mathrm{C}\right.$ environment, $\left.n=6\right)$, subjected to icepack application on the skin for $1 \mathrm{~h}$ (local ice bag, $n=5$ ) or given transdermal application of menthol ( $0.6 \mathrm{M}$ menthol in olive oil/Vaseline) (positive control, $n=6)$, or (ii) placed in a cold room $\left(4^{\circ} \mathrm{C}, n=6\right)$ for $3 \mathrm{~h}$. Data are shown as mean \pm s.e.m., each dot representing an individual mouse. $P$ values were determined using a two-tailed, Student's $t$-test. For the purpose of comparison, the SEAP levels from wild-type mice kept at room temperature (control, Fig. $\underline{3 a}$ ) were replicated. Statistics for (i) were performed by a one-way ANOVA test. c, The 24-h SEAP levels in the bloodstream of mice harboring intraperitoneal Coolsens $_{\text {implants and exposed to }}$ menthol vapor for $8 \mathrm{~h}$. Data are shown as mean \pm s.e.m.; $n=6$, each dot representing an 
individual mouse. Pvalues were determined using a two-tailed, Student's $t$-test between indicated datasets.

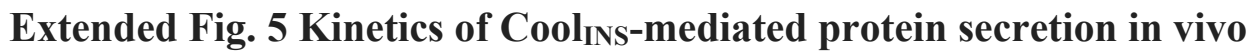

SEAP levels in the bloodstream sampled at different time points from mice harboring intraperitoneal $\mathrm{Cool}_{\text {Sens }}$ implants and receiving oral administrations of olive oil ( - menthol) or menthol $(0.15 \mathrm{M}$ in olive oil). Data are shown as mean \pm s.e.m., each dot representing an individual mouse ( $n=6$ mice per group). $P$ values were determined using a two-tailed, Student's $t$-test between indicated datasets.

\section{Extended Data Fig. 6 Long-term functionality of Cool INS cells in vivo}

a,b, T1D C57BL/6 mice $(n=7)$ were implanted with $2 \times 10^{6}$ Cool $_{\text {INS }}$ cells intraperitoneally and given oral administration of menthol solution $(0.3 \mathrm{M}$ in olive oil) at the indicated time points for 4 weeks. The placebo group received menthol without Cool INS cell implants $(n=5)$. Statistics were using a two-tailed, Student's $t$-test. a, Fasting blood glucose levels were measured at the indicated time points. $\mathbf{b}$, Intraperitoneal glucose tolerance test was performed on day 28. Healthy mice $(n=5)$ received no treatment. c, Impact of menthol on fasting glycemia in mice. T1D CD-1 mice $(n=6)$ were treated with topical menthol ointment $(0.6 \mathrm{M}$ menthol in olive oil/Vaseline) for $4 \mathrm{~d}$ and fasting blood glucose levels were assayed at indicated time points. Statistics were by one-way ANOVA test. Data are shown as mean \pm s.e.m.

\section{Extended Data Fig. 7 Long-term functionality of Coolsens cells in vivo}

a, Reversible transgene induction demonstrated with SEAP levels in the bloodstream of C57BL/6 mice harboring peritoneal Coolsens cell capsules and receiving repeated oral administrations of menthol $(0.3 \mathrm{M}$ in olive oil) for 5 weeks. Each dot represents an individual mouse ( $n=8$ mice, day 2 to day $16 ; n=6$ mice, day 19 to day 30). Data are shown as mean \pm s.e.m.; $P$ values were determined using a two-tailed, Student's $t$-test between indicated datasets. b, Macrophage depletion enhances transgene expression. One day before implantation of Coolsens cell capsules, C57BL/6 mice were treated with or without clodronate liposomes (single dose of $200 \mu \mathrm{l}$ intraperitoneally $n=6$ mice). Menthol ( $0.3 \mathrm{M}$ in olive oil) was orally administered to mice once a week before serum SEAP levels were assayed. For the purpose of comparison, the SEAP levels (weeks 1 and 2) from wild-type mice ( $n=8$ mice) (a) were replicated in $\mathbf{b}$. Data are shown as mean \pm s.e.m., each dot representing an individual mouse. $P$ values were determined using a two-tailed, Student's $t$-test between indicated datasets. c, Micrographs of cell capsules explanted from mice treated as described in $\mathbf{b}$ using peritoneal lavage. Experiments were repeated independently three times with similar results.

\section{Extended Data Fig. 8 Host immune response to designer cell implants}

a-d, Wild-type C57BL/6 mice were implanted intraperitoneally with empty capsules, capsules containing mouse-derived $\mathrm{C} 2 \mathrm{C} 12$ cells or capsules containing human-derived HEK-293

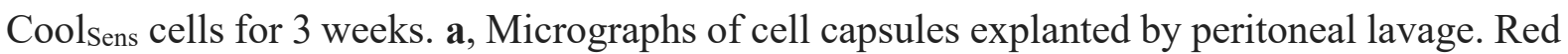
fluorescence indicates $\mathrm{Cool}_{\text {Sens }}$ cells. b, Retrieval efficacy of different cell capsules calculated 
by the percentage of retrievable microcapsules at week 3 post-transplantation in respect to the initial number of implanted cell capsules $(n=5$ mice). Data are shown as mean \pm s.e.m., $P$ values were determined using a two-tailed, Student's $t$-test between indicated datasets. c, Total count of cells retrieved by peritoneal lavage at week 3 post-implantation ( $n=5$ mice), Data are shown as mean \pm s.e.m. d, FACS analysis of the retrieved peritoneal cells described in $\mathbf{c}$ for different cell-surface markers $(n=4$ mice). Data are shown as mean \pm s.e.m. e-i, Wild-type C57BL/6 mice were implanted intraperitoneally with capsules containing human-derived HEK-293 Coolsens cells for 5 weeks while receiving oral menthol administration ( $0.3 \mathrm{M}$ in olive oil) once a week (same experimental group as in Extended Data Fig. 7a). Control groups received either no capsules or capsules containing HEK-293 cells lacking the $\mathrm{Cool}_{\text {sens }}$ circuit. e, Immunological characterization of spleen cell population in mice $(n=4$ mice Data are shown as mean \pm s.e.m. f, Total count of white blood cells, blood monocytes and blood lymphocytes in mice. White blood cell count (WBC) ( $n=6$ mice). Data are shown as mean \pm s.e.m. g, Serum TNF- $\alpha$ levels in mice. Statistics by one-way ANOVA test. NS ( $n=6$ mice). Data are shown as mean \pm s.e.m. Statistics by one-way ANOVA test. $\mathbf{h}$, Serum IFN- $\gamma$ levels in mice. Statistics by one-way ANOVA test $(n=6$ mice Data are shown as mean \pm s.e.m. i, Serum IL-6 levels in mice ( $n=6$ mice). Data are shown as mean \pm s.e.m. Each dot represents an individual mouse.

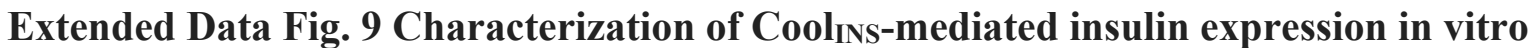

a, Insulin expression kinetics determined with ELISA of cell culture medium of $1 \times 10^{6} \mathrm{Cool}_{\text {INS }}$ cells cultivated in $2 \mathrm{ml}$ menthol-containing medium. Data presented are mean \pm s.d.; $n=3$ biologically independent samples. b. Functional assessment of insulin activity. Analogous to the assay described in Fig. 4b, phIR/MKp37/pLeo665-transfected HEK293 cells were cultivated with conditional medium from HEK-293 cells (control) or

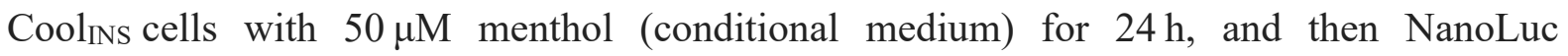
production in the supernatant was quantified. Data presented are mean \pm s.d.; $n=3$ biologically independent samples. 
No Menthol

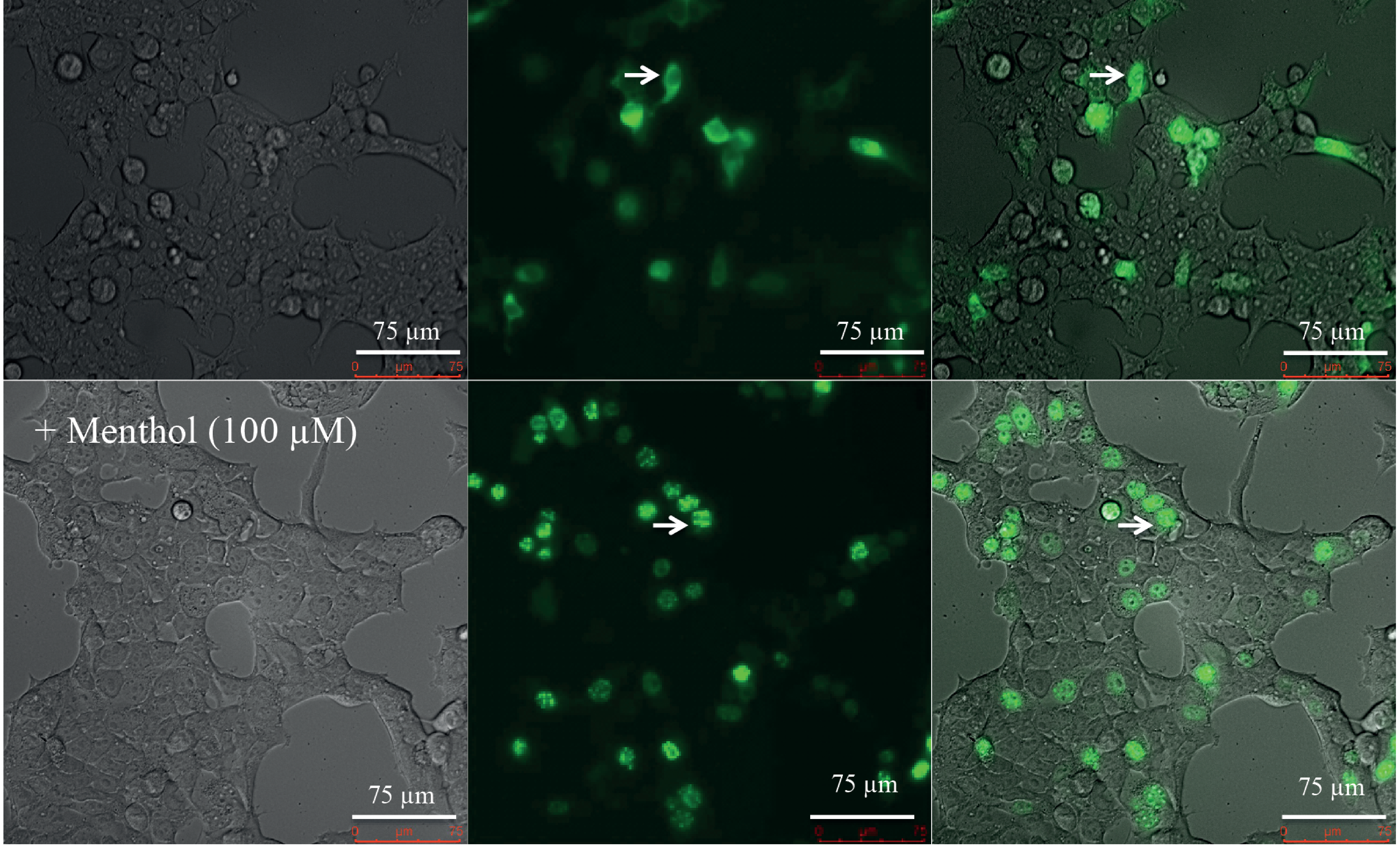

b
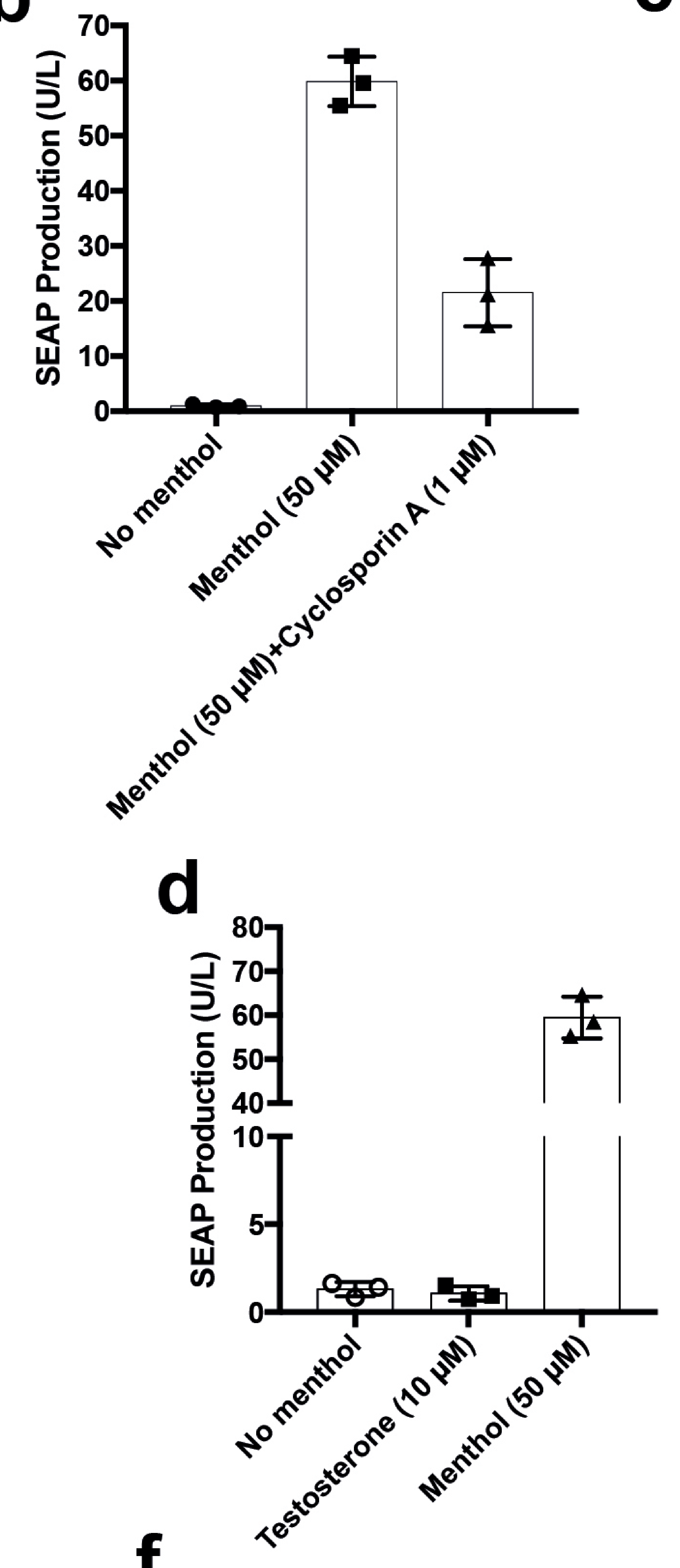

f

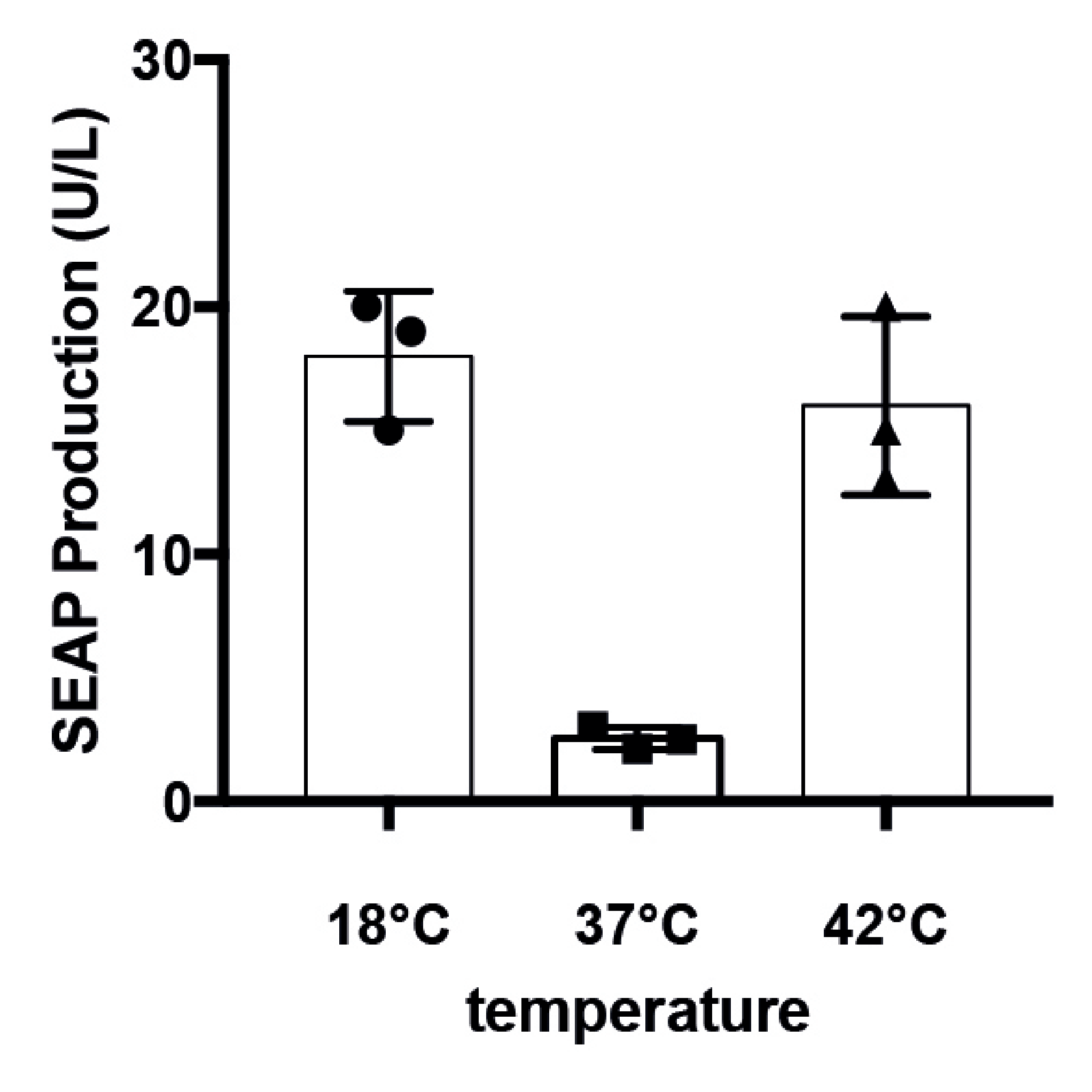

(i)

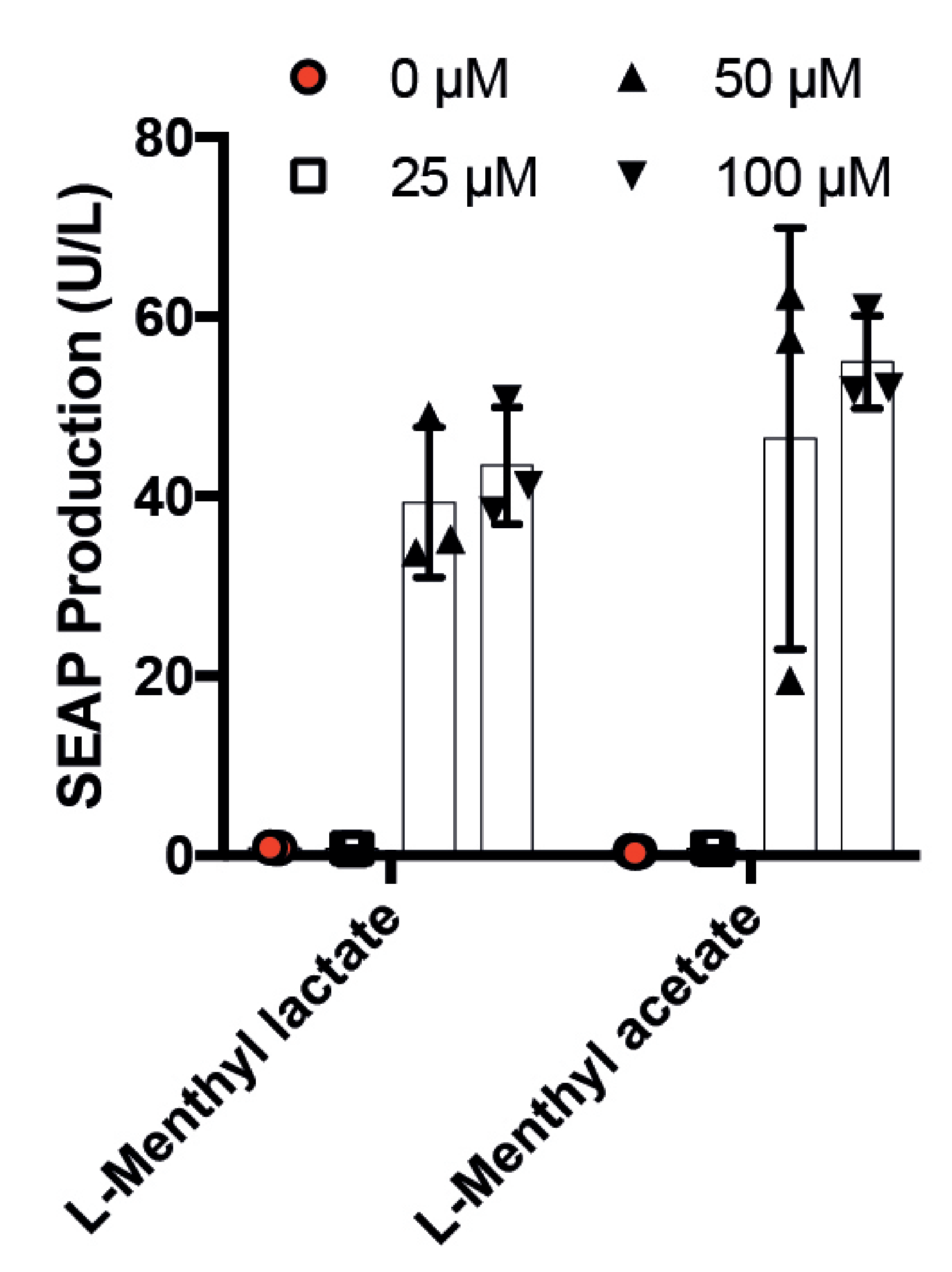

e

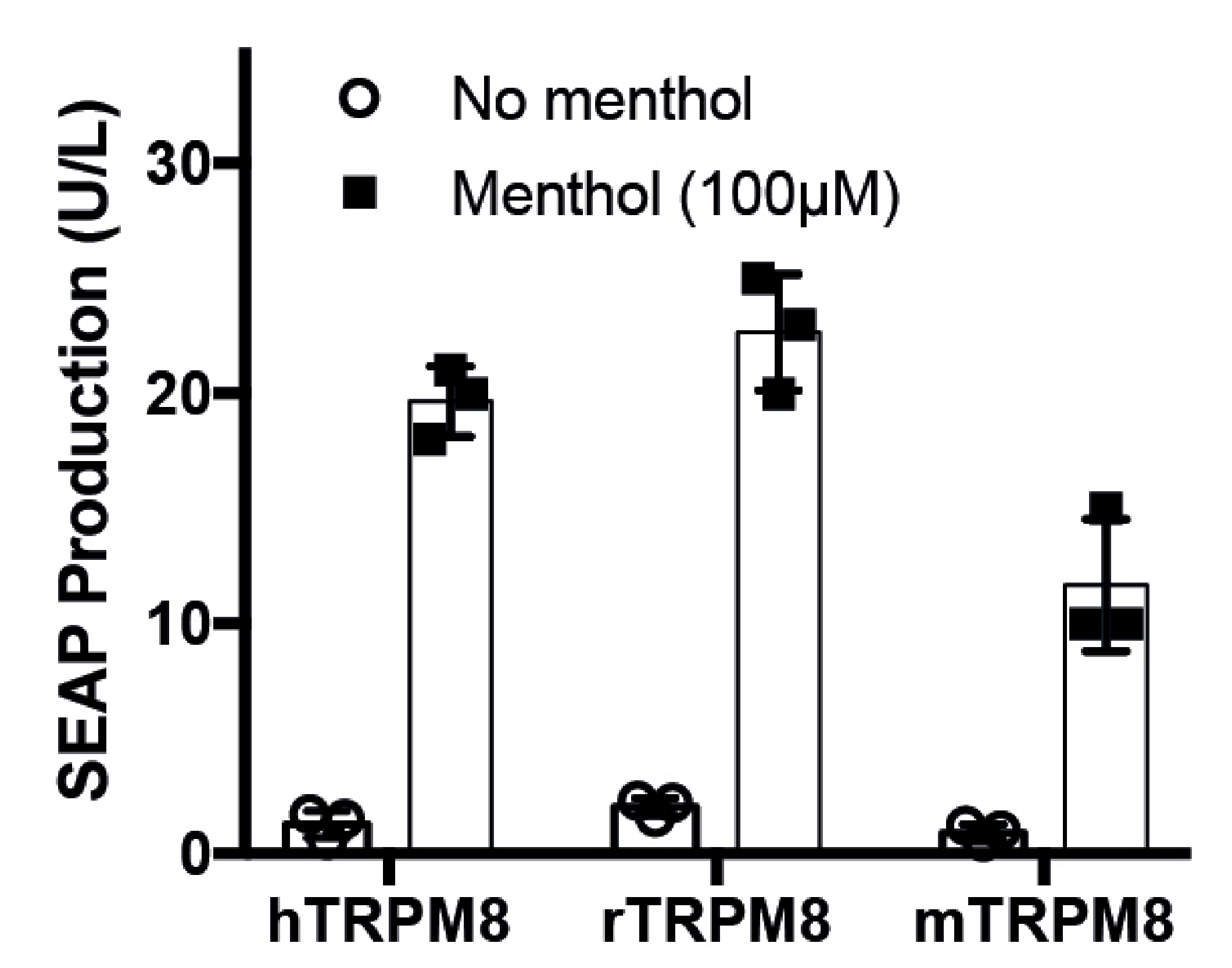

g

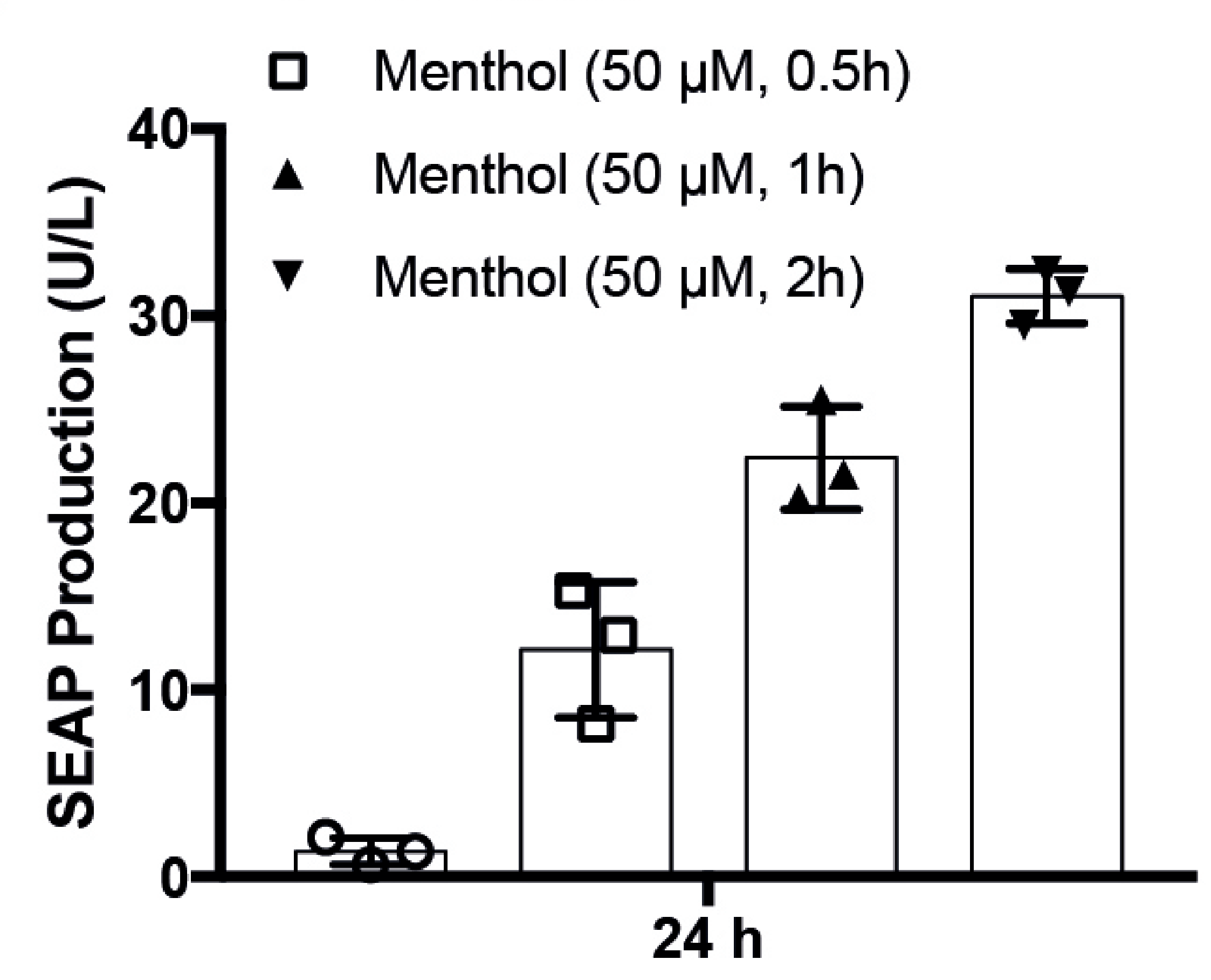

(iii)
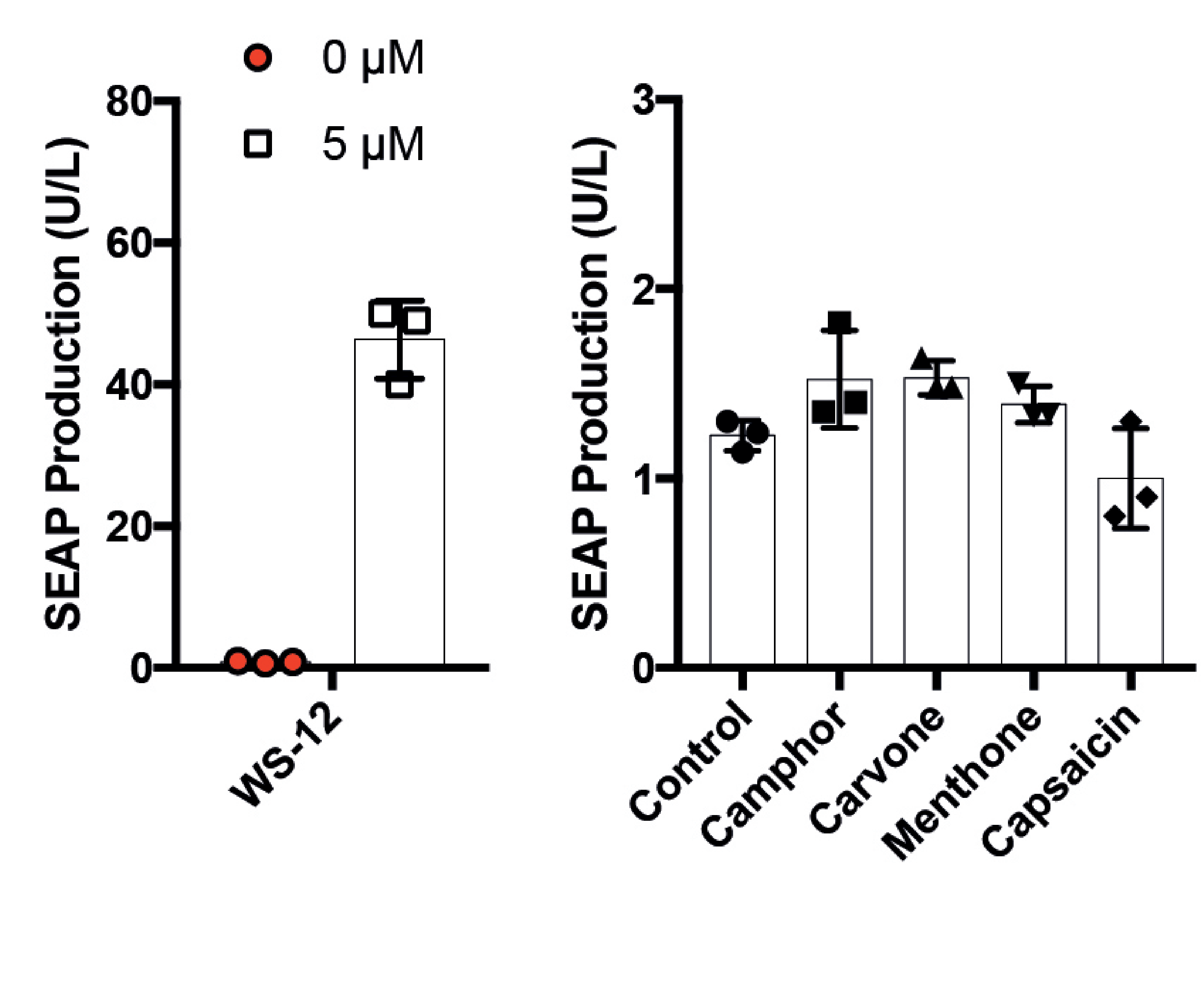
a

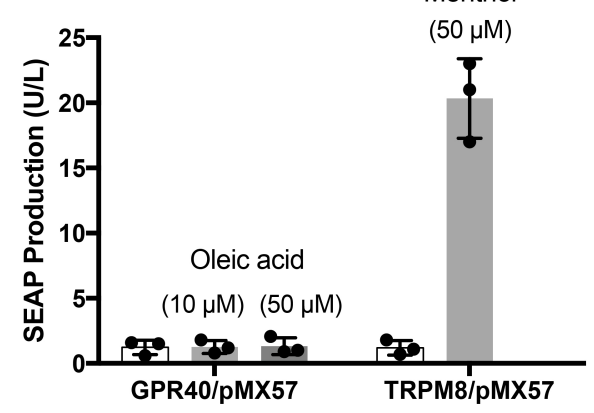

C $\quad \begin{array}{r}40- \\ 35- \\ \sum^{2} 30- \\ 25-\end{array}$

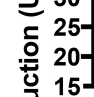

든 5
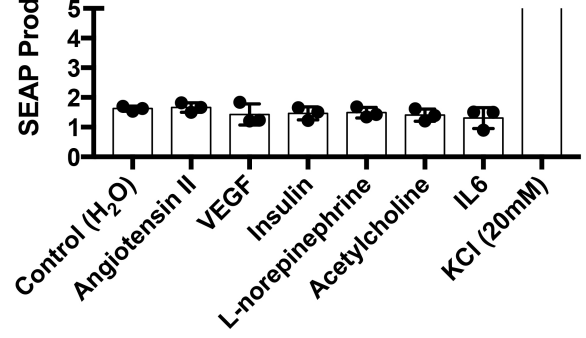

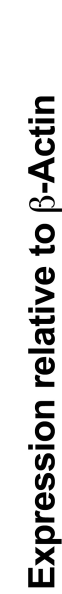

d
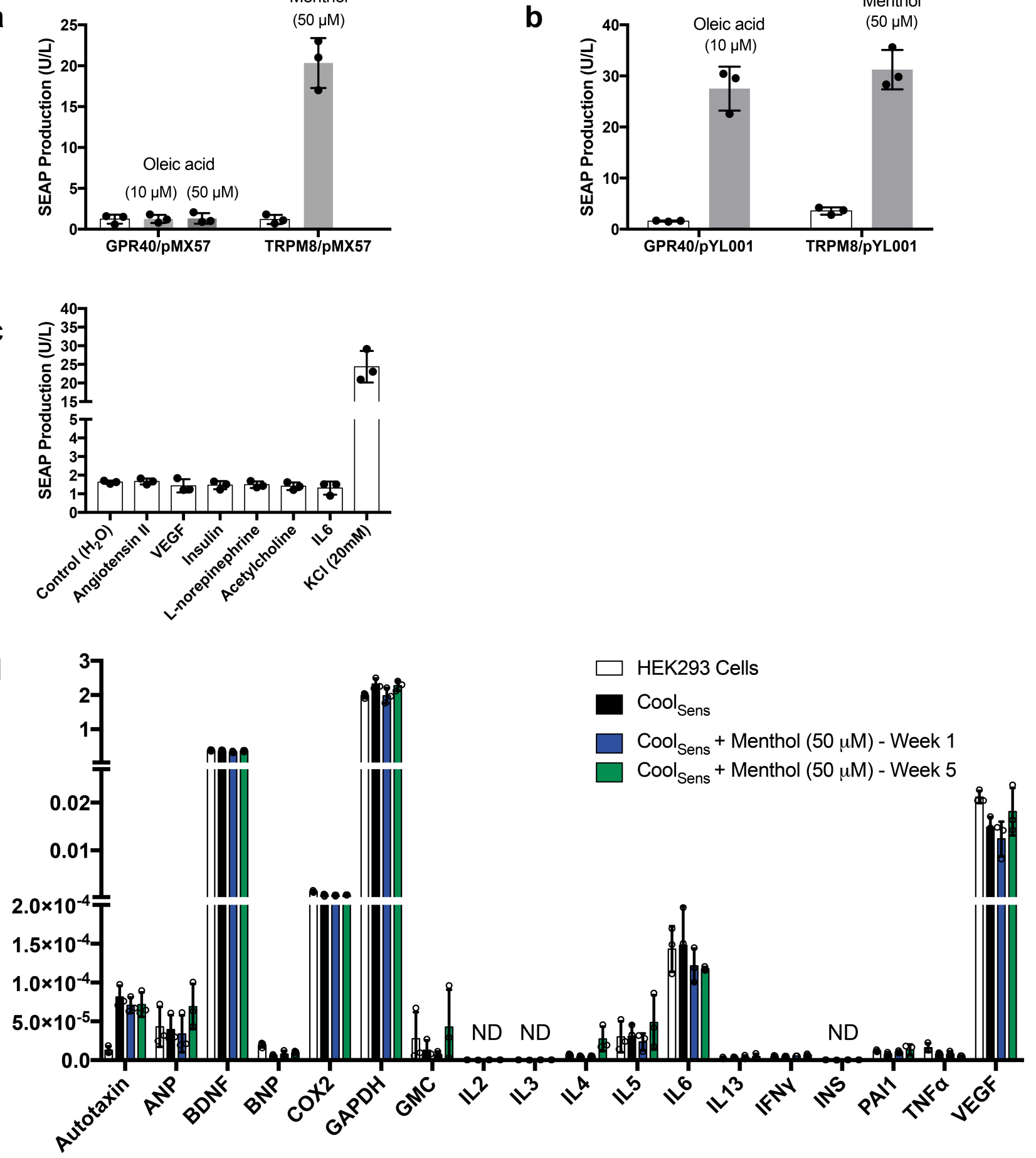

b 
Alginate

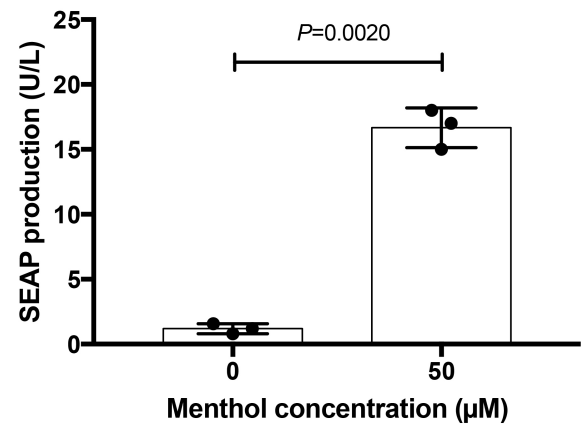

C

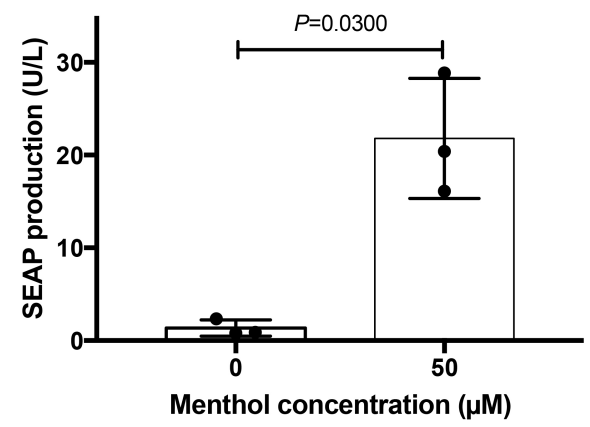

\section{Cellulose}

Hollow fiber

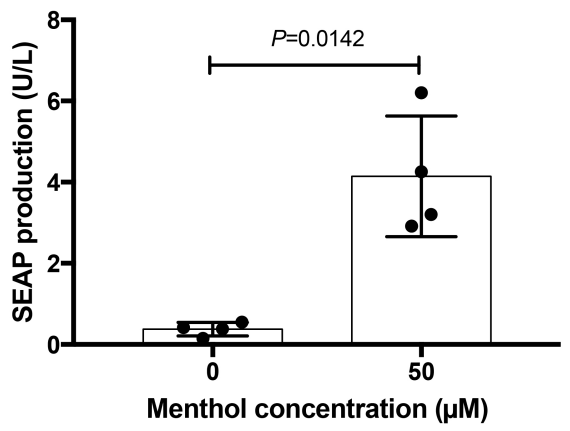




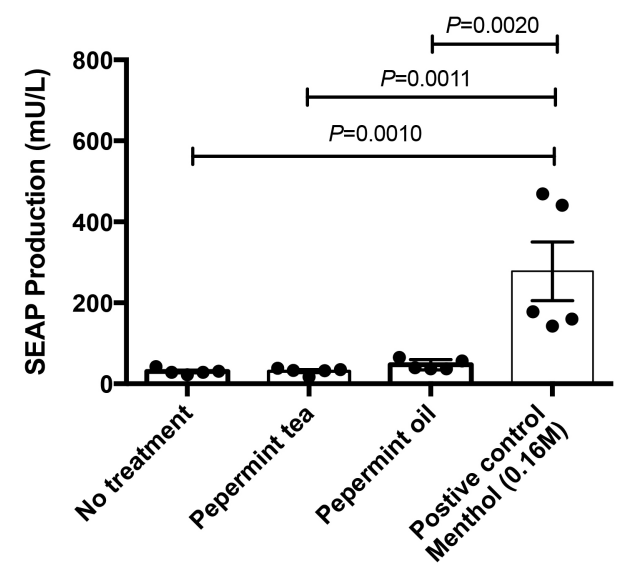

b
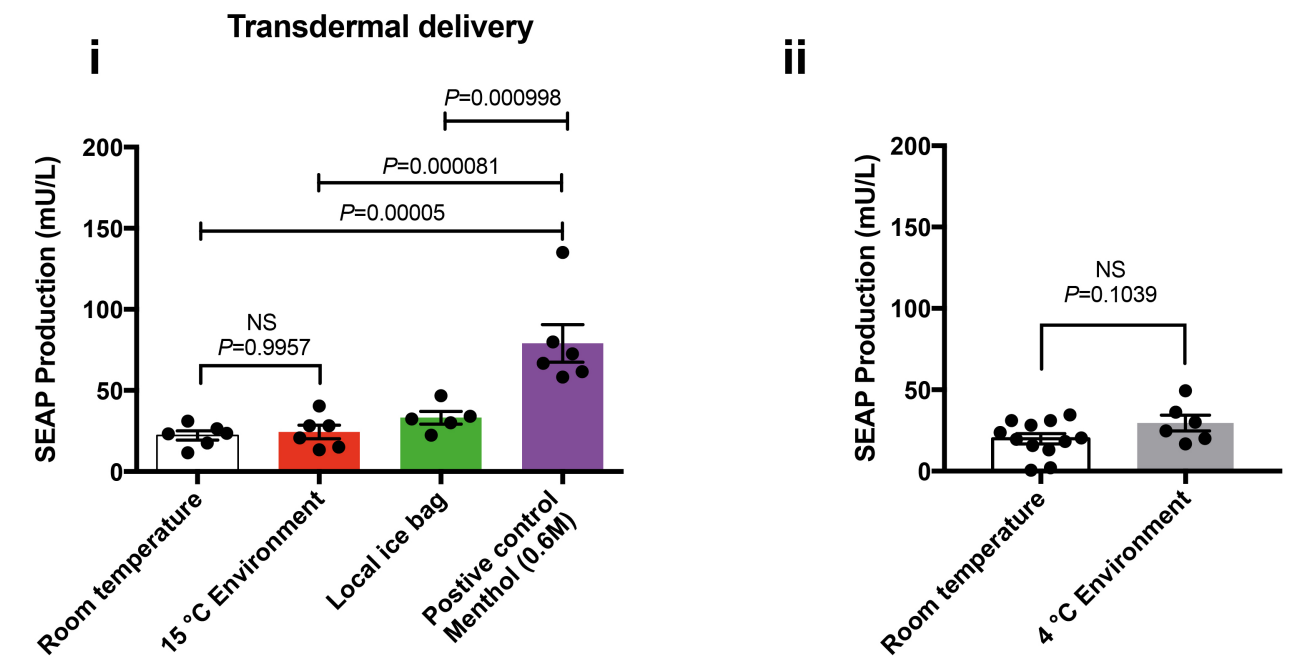

C

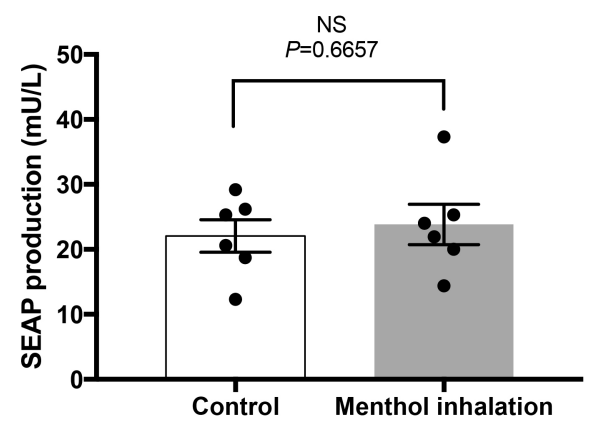


- No Menthol

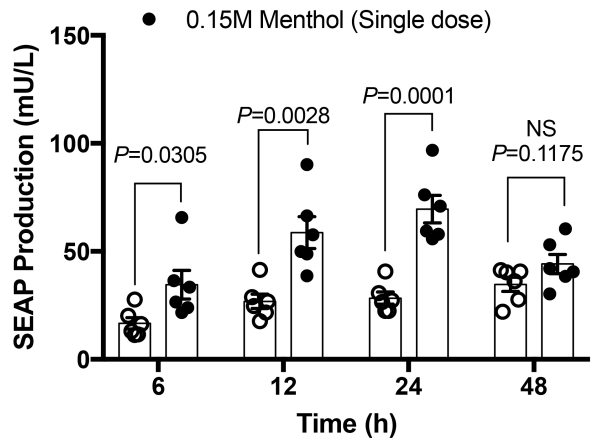




\section{GTT (Day 28)}

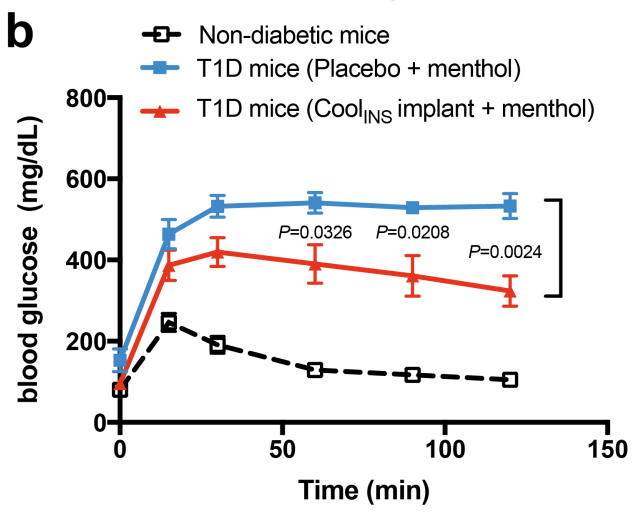

C

$\rightarrow-$ T1D mice (0.6M Menthol)

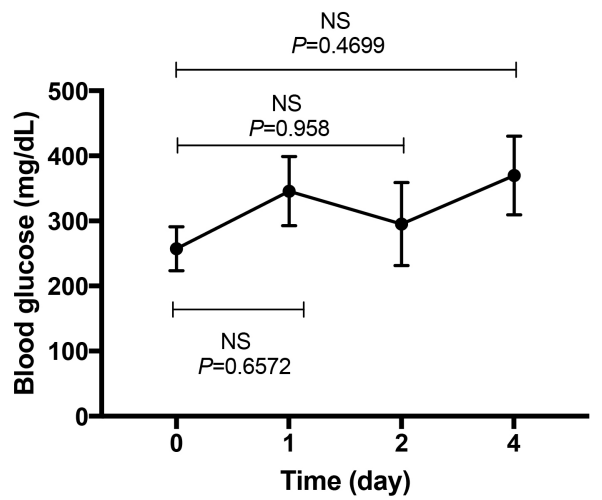


a

Empty capsule

$\mathrm{C} 2 \mathrm{C} 12$

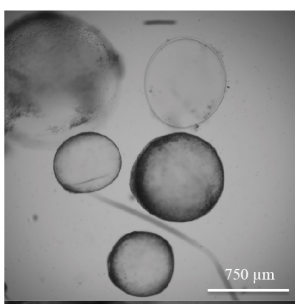

HEK293 Cool ${ }_{\text {sens }}$

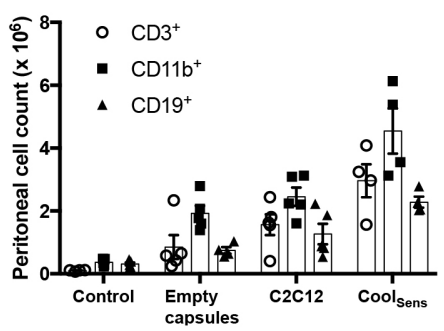

- Control

- HEK293

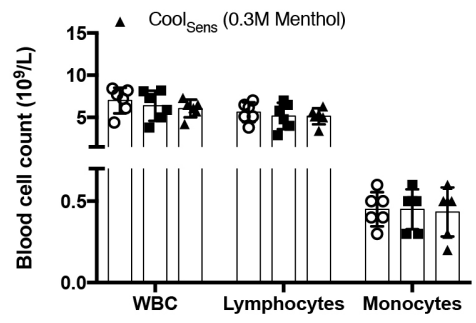

h

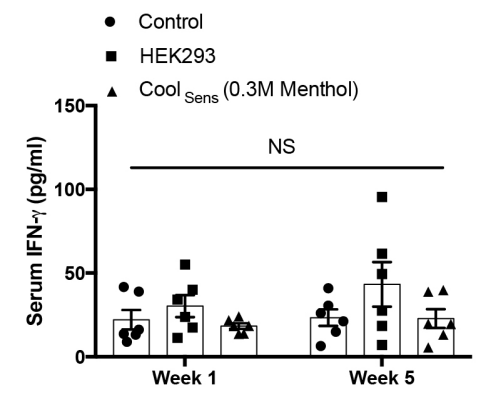

b

$P=0.0002$

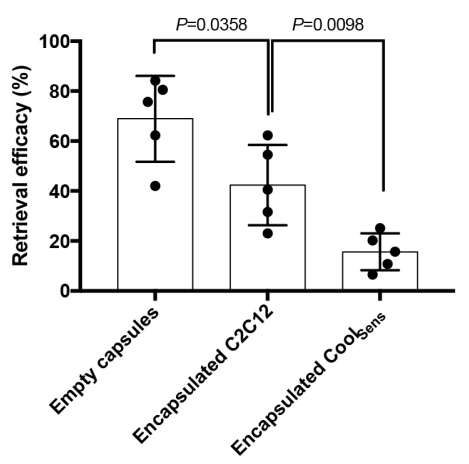

C

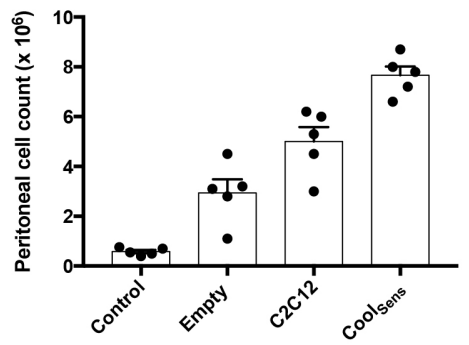

E 0 Control

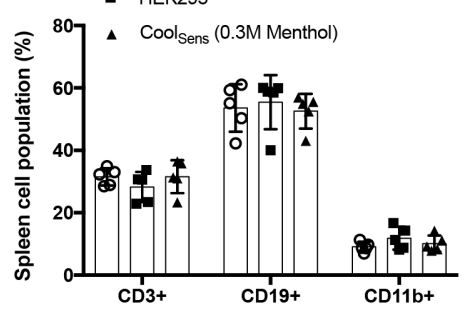

9 -

- Coolsens (0.3M Menthol)

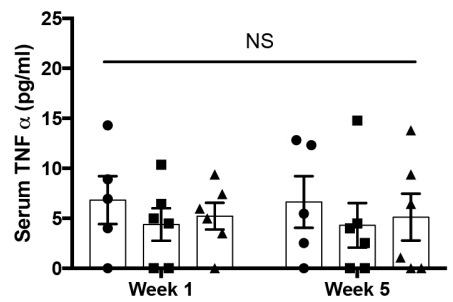

i

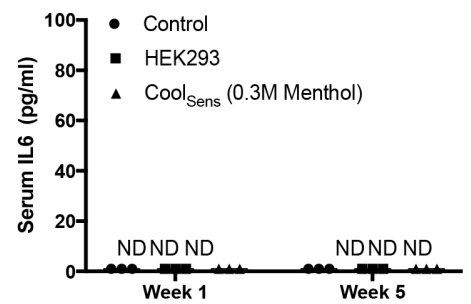


a

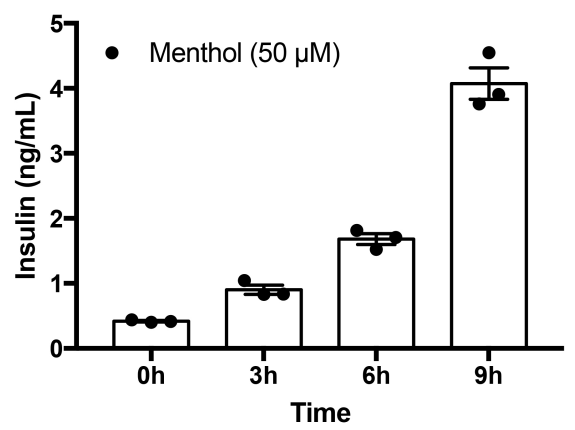

b

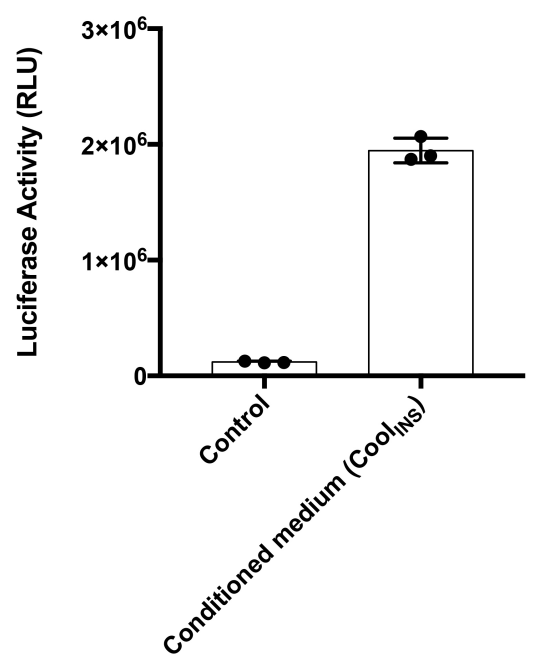

